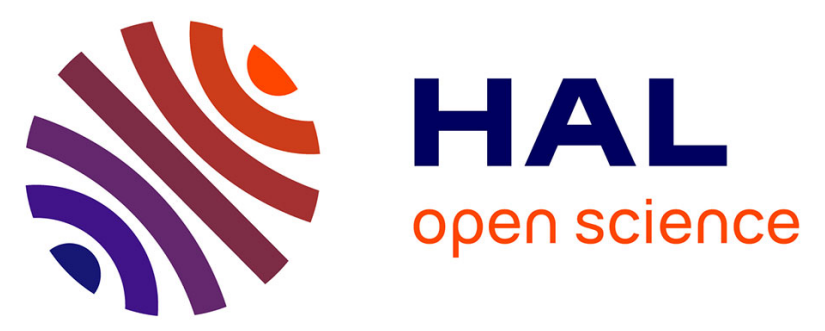

\title{
From monomeric complexes to double-stranded helicates constructed around trans-TiO4N2 motifs with intramolecular inter-ligand hydrogen-bonding interactions
}

Georges Khalil, Laurent Barloy, Nathalie Kyritsakas, Pierre Mobian, Marc Henry

\section{To cite this version:}

Georges Khalil, Laurent Barloy, Nathalie Kyritsakas, Pierre Mobian, Marc Henry. From monomeric complexes to double-stranded helicates constructed around trans-TiO4N2 motifs with intramolecular inter-ligand hydrogen-bonding interactions. Dalton Transactions, 2018, 47 (32), pp.11113-11122. $10.1039 / \mathrm{c} 8 \mathrm{dt} 01343 \mathrm{~h}$. hal-02353839

\section{HAL Id: hal-02353839 \\ https://hal.science/hal-02353839}

Submitted on 8 Dec 2021

HAL is a multi-disciplinary open access archive for the deposit and dissemination of scientific research documents, whether they are published or not. The documents may come from teaching and research institutions in France or abroad, or from public or private research centers.
L'archive ouverte pluridisciplinaire HAL, est destinée au dépôt et à la diffusion de documents scientifiques de niveau recherche, publiés ou non, émanant des établissements d'enseignement et de recherche français ou étrangers, des laboratoires publics ou privés. 


\title{
From monomeric complexes to double-stranded helicates constructed around trans- $\mathrm{TiO}_{4} \mathrm{~N}_{2}$ motifs with intramolecular inter-ligand hydrogen-bonding interactions.
}

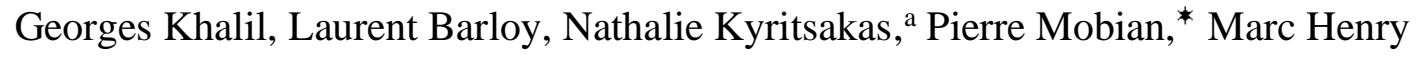 \\ Laboratoire de Chimie Moléculaire de l'Etat Solide, UMR 7140 UDS-CNRS, Université de Strasbourg, 4 rue Blaise Pascal, F-67000 \\ Strasbourg, France. \\ ${ }^{a}$ Laboratoire de Tectonique Moléculaire, UMR 7140 UDS-CNRS, Université de Strasbourg, 4 rue Blaise Pascal, F-67000 Strasbourg, \\ France.
}

Keywords: Self-assembly / helicate / $\mathrm{TiO}_{4} \mathrm{~N}_{2}$ / nitrogen monodentate ligands / hydrogen bond Abstract: A coordination chemistry involving trans- $\mathrm{TiO}_{4} \mathrm{~N}_{2}$ motifs is described, where the
oxygen ligands are 2,2'-biphenolato derivatives $\left(\mathrm{L}^{1}\right.$ or $\left.\mathrm{L}^{2}\right)$ and the nitrogen ligands are
pyridine (Pyr), 2,3-dihydro-7-azaindole (DHA) or 2-(methylamino)pyridine (MePyr). Monomeric complexes and double-stranded helicates incorporating this set of ligands are characterized. The monomeric species are obtained from the precursor $\left[\mathrm{Ti}\left(\mathrm{L}^{1}\right)_{2}\left(\mathrm{HO}^{\mathrm{i}} \mathrm{Pr}\right)_{2}\right]$ whereas the helical dinuclear architectures are synthetized by following a multicomponent self-assembly approach starting from $\mathrm{L}^{2} \mathrm{H}_{4}, \mathrm{Ti}\left(\mathrm{O}^{\mathrm{i} P r}\right)_{4}$ and two equivalents of the nitrogen ligand. It is proposed that the trans isomerism in $\mathrm{TiO}_{4} \mathrm{~N}_{2}$ observed in these structures results from the destabilisation of the cis isomer by the trans influence of the Ti-N bonds. The crystal structures and infra-red analysis demonstrate hydrogen bonding interactions occurring between the $\mathrm{NH}$ group of DHA or MePyr and the oxygens belonging to the titanium coordination sphere. The strength of these interactions is estimated with the PACHA (Partial Atomic Charges Analysis) software.

\section{Introduction}

The field of molecular self-assembled architectures driven by transition metals has seen an impressive expansion over the last three decades. ${ }^{1}$ Besides the serendipitous formation of these metallo-based structures, many efforts have been devoted to propose rational approaches permitting to generate such molecular entities. These strategies are based on the programmed recognition of the ligating properties of polytopic organic components by metal ions. Thus, an impressive number of rationally-designed helicates, ${ }^{2}$ cages,${ }^{3}$ squares,${ }^{4}$ spheres, ${ }^{5}$ grids, ${ }^{6}$ topological non-trivial molecules ${ }^{7}$ and other $\operatorname{architectures}^{8}$ have been reported.

In that domain, titanium(IV) center used as a connector occupies a particular place. Especially, octahedral $\mathrm{TiO}_{6}$ motifs have been extensively employed to create anionic architectures where the organic fragments incorporate catecholato units. ${ }^{9}$ 
Over the last decade, our group has developed a titanium(IV)-based coordination chemistry involving biphenolato-based ligands as shown in Figure 1a. ${ }^{10}$ This chemistry appeared to be well adapted to generate neutral self-assembled helical structures. ${ }^{11}$ Also, we reported the synthesis of monomeric heteroleptic complexes having a $\mathrm{TiO}_{4} \mathrm{~N}_{2}$ backbone using a series of nitrogen bidentate ligands. ${ }^{12}$ By following a multicomponent self-assembly approach, we extended this field of investigation to self-assembled helical architectures based on octahedral cis- $\mathrm{TiO}_{4} \mathrm{~N}_{2}$ motifs where nitrogen ligands adopt a bidentate chelating mode. ${ }^{13}$

Herein, we propose an extension of this coordination chemistry involving $\mathrm{TiO}_{4} \mathrm{~N}_{2}$ motifs by replacing nitrogen chelate by monodentate nitrogen ligands. Pyridine (Pyr) and two pyridine-type ligands (2,3-dihydro-7-azaindole (DHA), 2-(methylamino)pyridine (MePyr)) possessing an additional hydrogen donor site selected for this purpose are depicted in Figure 1b. Thus, the synthesis as well as the structural description of monomeric complexes and helical dinuclear species incorporating these selected monodentate ligands are reported.

\section{Results and discussion}

Synthesis and structural characterization of the monomeric $\left[\mathrm{Ti}\left(\mathrm{L}^{\mathbf{1}}\right)_{2}(\mathrm{Pyr})_{2}\right]$, $\left[\mathrm{Ti}\left(\mathrm{L}^{1}\right)_{2}(\mathrm{DHA})_{2}\right]$ and $\left[\mathrm{Ti}\left(\mathrm{L}^{1}\right)_{2}(\mathrm{MePyr})_{2}\right]$ complexes

As mentioned above, the synthesis of several monomeric titanium(IV) complexes with two substituted biphenolato ligands $\left(\mathrm{L}^{1}\right)$ incorporating various classical bidentate nitrogen ligands was described. ${ }^{12}$ Following the synthetic procedure allowing to generate this family of $\mathrm{TiO}_{4} \mathrm{~N}_{2}$-based compounds with nitrogen bidentate compounds, the reaction with Pyr starting from of the $\left[\mathrm{Ti}\left(\mathrm{L}^{1}\right)_{2}\left(\mathrm{HO}^{\mathrm{i} P r}\right)_{2}\right]$ precursor is firstly tested as detailed in the general equation 1.

$$
\left[\mathrm{Ti}\left(\mathrm{L}^{1}\right)_{2}\left(\mathrm{HO}^{\mathrm{i}} \mathrm{Pr}\right)_{2}\right]+2 \mathrm{~L} \rightarrow\left[\operatorname{Ti}\left(\mathrm{L}^{1}\right)_{2}(\mathrm{~L})_{2}\right]+2 \mathrm{HO}^{\mathrm{i} P r} \quad(\mathrm{~L}=\mathrm{Pyr}, \mathrm{DHA} \text { or MePyr })(\text { eq. } 1)
$$


a)

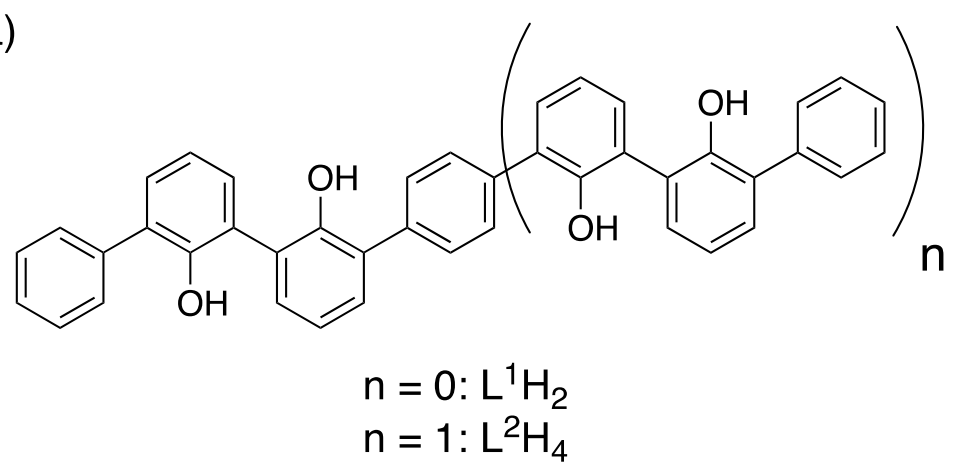

b)<smiles>c1ccncc1</smiles>

Pyr<smiles>c1cnc2c(c1)CCN2</smiles>

DHA<smiles>CNc1ccccn1</smiles>

MePyr

Fig. 1: a) Proligands $\mathrm{L}^{1} \mathrm{H}_{2}$ and $\mathrm{L}^{2} \mathrm{H}_{4} . \mathrm{L}^{2} \mathrm{H}_{4}$ incorporates two 2,2'-biphenol units linked with para-phenylene bridges. b) Pyridine (Pyr) and pyridine derivatives (DHA: 2,3-dihydro7-azaindole, MePyr: 2-(methylamino)pyridine).

The reaction is carried out in chloroform and diethyl ether vapours are allowed to slowly diffuse. Orange crystals are obtained after one day. Figure 2a shows the crystal structure of the $\left[\mathrm{Ti}\left(\mathrm{L}^{1}\right)_{2}(\mathrm{Pyr})_{2}\right]$ complex where the two Pyr ligands occupies trans positions within the metal octahedral coordination sphere. $\left[\mathrm{Ti}\left(\mathrm{L}^{1}\right)_{2}(\mathrm{Pyr})_{2}\right]$ crystallizes in a triclinic crystal system with a P-1 space group. The mean Ti-N and Ti-O distances are respectively $2.20 \pm 0.01 \AA$ and $1.89 \pm 0.02 \AA$. The structure shows the parallel arrangement between a OTi-O alignment and one Pyr ligand. Consequently, the two Pyr ligands are orthogonal one another. Also, the structure highlights hydrogen interactions between Pyr 2 and 6 hydrogens and the oxygens coordinated to the titanium centre as attested by the mean $\underline{\mathrm{C}} \mathrm{H} \bullet \bullet \underline{\mathrm{O}}$ distances and the mean $\mathrm{CH} \bullet \bullet \mathrm{O}$ angles $\left(3.20 \pm 0.01 \AA\right.$ and $\left.117.9 \pm 0.2^{\circ}\right)$. 
a)

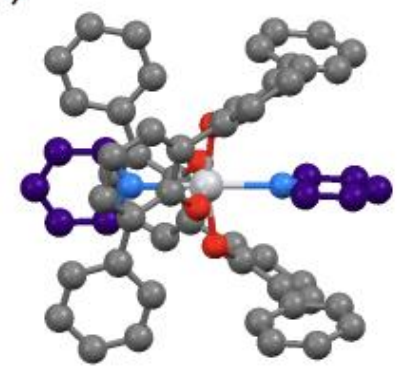

c)

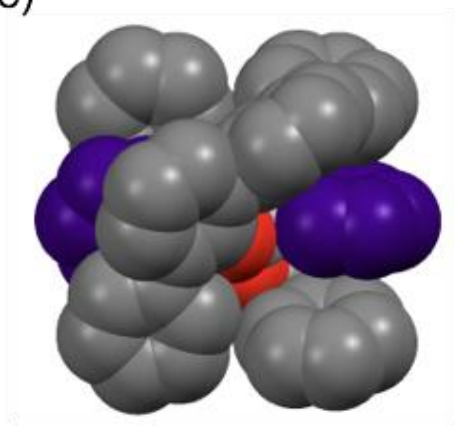

b)

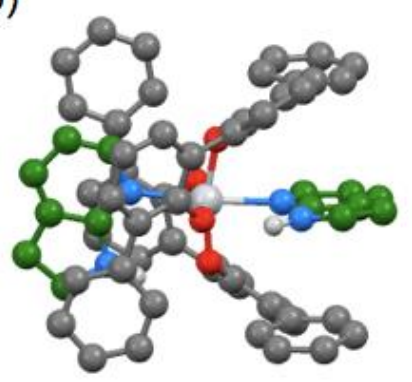

d)

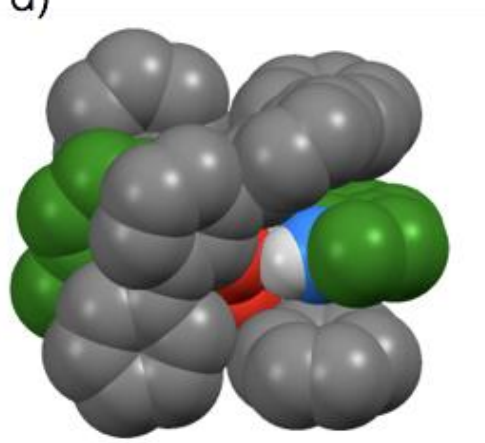

Fig. 2: Crystal structure of $\left[\mathrm{Ti}\left(\mathrm{L}^{1}\right)_{2}(\mathrm{Pyr})_{2}\right](\mathrm{a}$ and $\mathrm{c})$ and $\left[\mathrm{Ti}\left(\mathrm{L}^{1}\right)_{2}(\mathrm{DHA})_{2}\right](\mathrm{b}$ and d). The $\mathrm{L}^{1}$ carbons are in grey, oxygens are in red, nitrogen atoms are in blue, the Pyr carbons are in purple and the DHA carbons are in green. Hydrogen atoms are omitted for clarity except the NH hydrogens. In $\left[\mathrm{Ti}^{1}\left(\mathrm{~L}^{1}\right)_{2}(\mathrm{DHA})_{2}\right]$ structure, it should be noted that one DHA ligand is disordered on two positions, only one situation is shown.

The behaviour of the $\left[\mathrm{Ti}\left(\mathrm{L}^{1}\right)_{2}(\mathrm{Pyr})_{2}\right]$ complex in solution is studied by DOSY spectroscopy (see supporting information). $\left[\mathrm{Ti}\left(\mathrm{L}^{1}\right)_{2}(\mathrm{Pyr})_{2}\right]$ crystals are dissolved in $\mathrm{CDCl}_{3}$. At room temperature, a diffusion at $\mathrm{D}=660 \pm 60 \mu \mathrm{m}^{2} \cdot \mathrm{s}^{-1}$ is measured for the major species in solution. A good match is found between the experimental hydrodynamic radius $\left(\mathrm{R}_{h}\right)$ calculated with Stokes-Einstein equation $\left(\mathrm{R}_{h}\left[\mathrm{Ti}\left(\mathrm{L}^{1}\right)_{2}\left(\mathrm{Pyr}_{2}\right]\right.\right.$ in $\left.\mathrm{CDCl}_{3}\right)=6.2 \pm 0.6 \AA$ ) and the theoretically one computed from the crystal structure $\left(\mathrm{R}_{h}=5.7 \pm 0.6 \AA\right) .{ }^{14}$ This indicates that the structure characterized in the solid-state is maintained in solution and no decoordination of the Pyr ligands occurred. This observation contrasts strongly with the behaviour observed for some Ti(IV)-based complexes bearing monodentate ligands ${ }^{10,15}$. Additionally, by DOSY, a second diffusion is measured attributed to $\mathrm{L}^{1} \mathrm{H}_{2}$ presents in a minor amount, indicating the rather moderate stability of $\left.\left[\mathrm{Ti}^{(} \mathrm{L}^{1}\right)_{2}(\mathrm{Pyr})_{2}\right]$ in chloroform.

To understand the factors allowing the trans isomerism in $\left[\mathrm{Ti}\left(\mathrm{L}^{1}\right)_{2}(\mathrm{Pyr})_{2}\right]$, the cis$\left[\mathrm{Ti}\left(\mathrm{L}^{1}\right)_{2}(\mathrm{Pyr})_{2}\right]$ and trans-[Ti( $\left.\left(\mathrm{L}^{1}\right)_{2}(\mathrm{Pyr})_{2}\right]$ are modelled using DFT calculations with the 
B3LYP hybrid functional and cc-pVTZ basis functions (see the modelled structures in Figure 3). The structures are optimized with the GAUSSIAN09 Revision D01 software ${ }^{16}$ allowing to derive a gas phase energy, and next are imported in the PACHA software for retrieving selfenergies as well as bonded steric energies (table 1). The self-energy is estimated from atomic coordinates after computation of a partial charge distribution using an electronegativity equalization scheme based on a non-empirical set of electronegativities and atomic radii. ${ }^{17}$ Formally, it approximates the $\int \rho(r) \cdot v(r) \cdot d r$ part of the total energy in Hohenberg-Kohn's density functional theory (DFT). The bonded steric energy is a non-empirical estimate of the electronic energy functional, using short-range repulsive potentials derived from the GordonKim electron gas model. ${ }^{18}$ Neither the energies in gas phase nor the self-energy permit to explain the predominance of the trans $-\left[\mathrm{Ti}\left(\mathrm{L}^{1}\right)_{2}(\mathrm{Pyr})_{2}\right]$ isomer. In particular, the self-energy is as expected much in favour of $c i s-\left[\mathrm{Ti}\left(\mathrm{L}^{1}\right)_{2}(\mathrm{Pyr})_{2}\right]$. Clearly, the preferential trans isomerism versus cis is originated from the bonded steric energy factor that fully counterbalances the electrostatic balance, since by summing all the $\Delta \mathrm{E}($ trans-cis $)$ energies a difference of -18.7 $\mathrm{kJ} . \mathrm{mol}^{-1}$ in favour of trans- $\left[\mathrm{Ti}\left(\mathrm{L}^{1}\right)_{2}(\mathrm{Pyr})_{2}\right]$ is found. The most favourable bonded steric energy for trans-[Ti( $\left.\left(\mathrm{L}^{1}\right)_{2}(\mathrm{Pyr})_{2}\right]$ is proposed to result from the longer Ti-O bonds found in trans$\left[\mathrm{Ti}\left(\mathrm{L}^{1}\right)_{2}(\mathrm{Pyr})_{2}\right]$ compared to the same linkage in $c i s-\left[\mathrm{Ti}\left(\mathrm{L}^{1}\right)_{2}(\mathrm{Pyr})_{2}\right]$ (mean Ti-O distances in trans-[Ti( $\left.\left(\mathrm{L}^{1}\right)_{2}(\mathrm{Pyr})_{2}\right]: 1.913 \AA$; mean Ti-O distances in $\left.c i s-\left[\operatorname{Ti}\left(\mathrm{L}^{1}\right)_{2}(\mathrm{Pyr})_{2}\right]: \quad 1.879 \AA\right)$. Particularly, as the two shortest Ti-O bonds in cis-[Ti( $\left.\left(\mathrm{L}^{1}\right)_{2}(\mathrm{Pyr})_{2}\right]$ are in trans to the Ti-N bonds, this highlights the trans influence of the Ti-O bonds in $c i s-\left[\mathrm{Ti}\left(\mathrm{L}^{1}\right)_{2}(\mathrm{Pyr})_{2}\right] .{ }^{19}$

a)

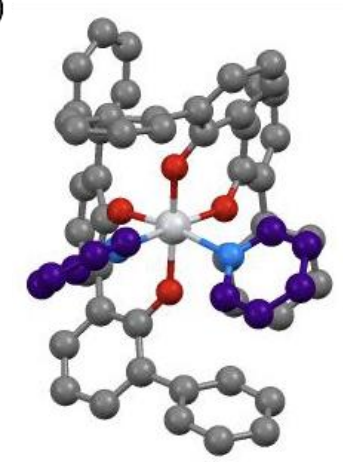

b)

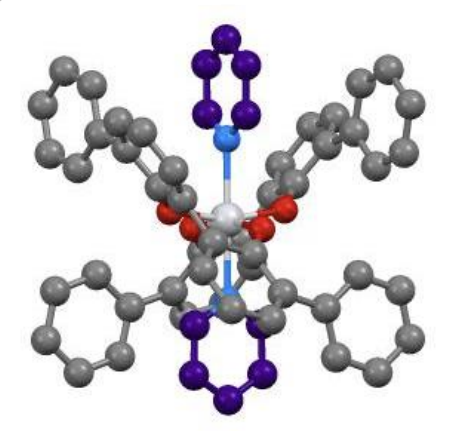

Fig. 3: Modelled structures of cis- $\left[\mathrm{Ti}\left(\mathrm{L}^{1}\right)_{2}(\mathrm{Pyr})_{2}\right]$ and trans- $\left[\mathrm{Ti}\left(\mathrm{L}^{1}\right)_{2}(\mathrm{Pyr})_{2}\right]$ computed with the GAUSSIAN09 Revision D01 software. The $\mathrm{L}^{1}$ carbons are in grey, the oxygens are in red, Pyr carbons are in purple and nitrogen atoms are in blue. Hydrogen atoms are omitted for clarity. 


\begin{tabular}{|c|c|c|c|}
\hline & $\begin{array}{c}\text { trans- }\left[\mathrm{Ti}\left(\mathrm{L}^{1}\right)_{2}(\mathrm{Pyr})_{2}\right] \\
\left(\mathrm{kJ} \cdot \mathrm{mol}^{-1}\right)\end{array}$ & $\begin{array}{c}\text { cis- }\left[\mathrm{Ti}\left(\mathrm{L}^{1}\right)_{2}(\mathrm{Pyr})_{2}\right] \\
\left(\mathrm{kJ} \cdot \mathrm{mol}^{-1}\right)\end{array}$ & $\begin{array}{c}\Delta \mathrm{E}(\text { trans-cis }) \\
\left(\mathrm{kJ} . \mathrm{mol}^{-1}\right)\end{array}$ \\
\hline Total energy & -14629.483 & -14629.453 & -0.030 \\
\hline Self-energy & -3776.9 & -3897.1 & 120.2 \\
\hline Bonded steric energy & 3705.2 & 3844.1 & -138.9 \\
\hline
\end{tabular}

Table 1: Energies, self-energies and bonded steric energies calculated for $c i s-\left[\operatorname{Ti}\left(\mathrm{L}^{1}\right)_{2}(\mathrm{Pyr})_{2}\right]$ and trans-[Ti( $\left.\left.\mathrm{L}^{1}\right)_{2}(\mathrm{Pyr})_{2}\right]$. Energies in gas phase were computed with the GAUSSIAN09 Revision D01 software whereas electrostatic balances and bonded steric energies were determined with the PACHA software. ${ }^{20}$

Next, the complexation of two nitrogen monodentate ligands possessing an additional hydrogen bond donor NH group is examined. As the X-ray crystal structure of trans$\left[\mathrm{Ti}\left(\mathrm{L}^{1}\right)_{2}(\mathrm{Pyr})_{2}\right]$ highlighted $\mathrm{CH} \bullet \bullet \mathrm{O}$ interactions, we wanted to incorporate in these structures ligands that are capable to generate strong intramolecular inter-ligand $\mathrm{NH} \bullet \bullet \mathrm{O}$ interactions. Therefore, DHA and MePyr have been selected for this purpose. A synthetic procedure similar to the one used to generate $\left[\mathrm{Ti}\left(\mathrm{L}^{1}\right)_{2}(\mathrm{Pyr})_{2}\right]$ is applied for the synthesis of $\left[\mathrm{Ti}\left(\mathrm{L}^{1}\right)_{2}(\mathrm{DHA})_{2}\right]$ and $\left[\mathrm{Ti}\left(\mathrm{L}^{1}\right)_{2}(\mathrm{MePyr})_{2}\right]$. Crystals of $\left[\mathrm{Ti}\left(\mathrm{L}^{1}\right)_{2}(\mathrm{DHA})_{2}\right]$ are obtained when the reaction is performed in $\mathrm{CHCl}_{3}$ and $n$-pentane vapours slowly allowed to diffuse in this mixture. The structure of $\left[\mathrm{Ti}\left(\mathrm{L}^{1}\right)_{2}(\mathrm{DHA})_{2}\right]$ is shown in figure $2 \mathrm{~b}$. Again, a trans isomerism is observed for the complex. Importantly, in the crystal structure, one DHA ligand is disordered on two positions. Figure 4 shows a simplified schematic drawing representing the two diastereoisomers resulting from this disorder. The mean Ti-N and Ti-O distances are respectively found to be $2.21 \pm 0.02 \AA$ and $1.89 \pm 0.02 \AA$. Hydrogen $\mathrm{NH} \bullet \bullet \mathrm{O}$ bonding provides the alignment between one DHA ligand and one of the trans-O-Ti-O fragment. Therefore, the two DHA ligands are orthogonal one another. The mean distances $\underline{N} H \bullet \bullet \underline{O}$ and the NH॰•O angles respectively of $2.93 \pm 0.01 \AA$ and $144.6 \pm 0.3^{\circ}$ confirm these interactions. It should be noted that $\mathrm{NH} \bullet \bullet \mathrm{O}$ interactions are usually met when adenine-type ligands are incorporating into complexes containing M-O linkage. ${ }^{21}$ 

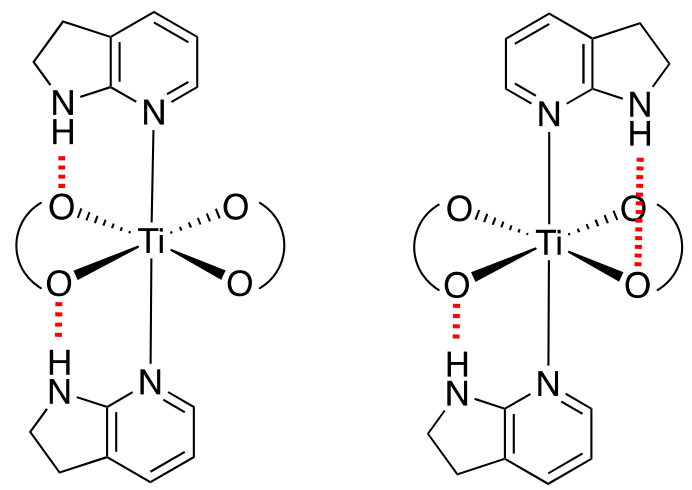

$\left.\begin{array}{l}O \\ O\end{array}\right)=L^{1}$

Fig. 4: Schematic drawing of the two positions adopted by one DHA ligand in the crystal structure of $\left[\mathrm{Ti}\left(\mathrm{L}^{1}\right)_{2}(\mathrm{DHA})_{2}\right]$.

In solution $\left(\mathrm{CDCl}_{3}\right)$, an excellent match is found between the experimental $\mathrm{R}_{\mathrm{h}}$ value of the complex $\left(\mathrm{R}_{\mathrm{h}}=5.88 \pm 0.6 \AA\right.$ for a diffusion of $\left.\mathrm{D}=650 \pm 65 \mu \mathrm{m}^{2} . \mathrm{s}^{-1}\right)$ determined by DOSY and the theoretical $R_{h}\left(R_{h}=5.91 \pm 0.6 \AA\right)$ evaluated from the crystal structure. Again, this result attests the non-labile behaviour of these nitrogen ligands. Remarkably, two sets of signals in equal proportion are observed for the complex by ${ }^{1} \mathrm{H}$ and ${ }^{13} \mathrm{C}$ NMR that match with the presence in solution of two diastereoisomers. Indeed, this result is in full accordance with the disorder of one DHA ligand within $\left[\mathrm{Ti}\left(\mathrm{L}^{1}\right)_{2}(\mathrm{DHA})_{2}\right]$ highlighted by the X-ray crystal analysis. Also, as it is observed for $\left[\mathrm{Ti}\left(\mathrm{L}^{1}\right)_{2}(\mathrm{Pyr})_{2}\right]$, traces of the $\mathrm{L}^{1} \mathrm{H}_{2}$ and free DHA ligands are detected by ${ }^{1} \mathrm{H}$ NMR probably originated from the rather instable $\left[\operatorname{Ti}\left(\mathrm{L}^{1}\right)_{2}(\mathrm{DHA})_{2}\right]$ complex when it is dissolved in $\mathrm{CDCl}_{3}$.

Crystals of the $\left[\mathrm{Ti}\left(\mathrm{L}^{1}\right)_{2}(\mathrm{MePyr})_{2}\right]$ complex are obtained but their qualities were not suitable for X-ray crystal analysis. Nevertheless, the $\left[\mathrm{Ti}\left(\mathrm{L}^{1}\right)_{2}(\mathrm{MePyr})_{2}\right]$ formula is undoubtedly attributed to this compound according ${ }^{1} \mathrm{H}$ and ${ }^{13} \mathrm{C} \mathrm{NMR}$ analysis, infrared spectroscopy and elemental analysis. According to NMR analysis, the same behaviour as $\left[\mathrm{Ti}\left(\mathrm{L}^{1}\right)_{2}(\mathrm{DHA})_{2}\right]$ is observed in solution i.e. the presence of two diastereoisomers. For instance by ${ }^{1} \mathrm{H}$ NMR, two doublets $(\mathrm{J}=4.9 \mathrm{~Hz})$ are observed for the NMR signature of the Me groups belonging to the MePyr ligands within the complex that underlies the presence of two diastereoisomers in solution as it is observed for $\left[\mathrm{Ti}\left(\mathrm{L}^{1}\right)_{2}(\mathrm{DHA})_{2}\right]$.

Synthesis and structural characterization of the double stranded helicates $\left[\mathrm{Ti}_{2}\left(\mathrm{~L}^{2}\right)_{2}(\mathrm{Pyr})_{4}\right],\left[\mathrm{Ti}_{2}\left(\mathrm{~L}^{2}\right)_{2}(\mathrm{DHA})_{4}\right]$ and $\left[\mathrm{Ti}_{2}\left(\mathrm{~L}^{2}\right)_{2}(\mathrm{MePyr})_{4}\right]$ 
Next, the trans- $\mathrm{TiO}_{4} \mathrm{~N}_{2}$ motif is used to generate architectures incorporating the $\mathrm{L}^{2}$ strand based on a multicomponent self-assembly approach. The monodentate nitrogen ligands react in hot toluene $\left(100{ }^{\circ} \mathrm{C}\right)$ with titanium isopropoxide and $\mathrm{L}^{2} \mathrm{H}_{4}$ as detailed in eq. 2.

$$
2 \mathrm{Ti}\left(\mathrm{O}^{\mathrm{i} P r}\right)_{4}+2 \mathrm{~L}^{2} \mathrm{H}_{4}+4 \mathrm{~L} \rightarrow\left[\mathrm{Ti}_{2}\left(\mathrm{~L}^{1}\right)_{2}(\mathrm{~L})_{4}\right]+8 \mathrm{HO}^{\mathrm{i}} \mathrm{Pr} \quad(\mathrm{L}=\mathrm{Pyr}, \mathrm{DHA} \text { or MePyr }) \text { (eq. 2) }
$$

In these three cases, red-orange crystals suitable for X-ray analysis are formed directly in the hot solution. The structures of $\left[\mathrm{Ti}_{2}\left(\mathrm{~L}^{2}\right)_{2}(\mathrm{Pyr})_{4}\right], \quad\left[\mathrm{Ti}_{2}\left(\mathrm{~L}^{2}\right)_{2}(\mathrm{DHA})_{4}\right]$ and $\left[\mathrm{Ti}_{2}\left(\mathrm{~L}^{2}\right)_{2}(\mathrm{MePyr})_{4}\right]$ are shown in Figure 5. The three dimeric helical complexes are quasiisostructural. However, a significant difference between these architectures concerns the hydrogen bond networks. In $\left[\mathrm{Ti}_{2}\left(\mathrm{~L}^{2}\right)_{2}(\mathrm{MePyr})_{4}\right]$ only one $\mathrm{L}^{2}$ strand is involved in intramolecular $\mathrm{NH} \bullet \bullet \mathrm{O}$ interactions with the four MePyr ligands whereas both bisbiphenolato fragments interact with the four DHA ligands in $\left[\mathrm{Ti}_{2}\left(\mathrm{~L}^{2}\right)_{2}(\mathrm{DHA})_{4}\right]$. Table 2 gathers the mean Ti-O, Ti-N distances as well as the $\underline{\mathrm{NH}} \bullet \bullet \underline{\mathrm{O}}$ or $\underline{\mathrm{C}} \mathrm{H} \bullet \bullet \underline{\mathrm{O}}$ distances and angles measured in these complexes. Also, Table 2 indicates almost identical Tiø••Ti distances found in each complex. The dihedral angles between the two planes containing the para-phenylene bridges are $77.6^{\circ}, 75.9^{\circ}, 72.2^{\circ}$ for $\left[\mathrm{Ti}_{2}\left(\mathrm{~L}^{2}\right)_{2}(\mathrm{Pyr})_{4}\right],\left[\mathrm{Ti}_{2}\left(\mathrm{~L}^{2}\right)_{2}(\mathrm{DHA})_{4}\right]$ and $\left[\mathrm{Ti}_{2}\left(\mathrm{~L}^{2}\right)_{2}(\mathrm{MePyr})_{4}\right]$ respectively. This situation contrasts strongly with a related double-stranded helicate constructed around two cis- $\mathrm{TiO}_{4} \mathrm{~N}_{2}$ motifs, where $\mathrm{CH}-\pi$ interactions occur between the two central aromatic units belonging to $\mathrm{L}^{2} .^{22}$ These compounds are chiral owing to their inherent helicity. In these crystals, the $P$ and $M$ helicates are found in equal proportion since all these structures belong to centrosymmetric space groups. In Figure 5 is shown the $\left[\mathrm{Ti}_{2}\left(\mathrm{~L}^{2}\right)_{2}(\mathrm{Pyr})_{4}\right]$ and $\left[\mathrm{Ti}_{2}\left(\mathrm{~L}^{2}\right)_{2}(\mathrm{DHA})_{4}\right]$ complexes displaying a $M$ helicity, and the $\left[\mathrm{Ti}_{2}\left(\mathrm{~L}^{2}\right)_{2}(\mathrm{MePyr})_{4}\right]$ adopting a $P$ helicity. Another views of the helical arrangement of one strand within $\left[\mathrm{Ti}_{2}\left(\mathrm{~L}^{2}\right)_{2}(\mathrm{MePyr})_{4}\right]$ and $\left[\mathrm{Ti}_{2}\left(\mathrm{~L}^{2}\right)_{2}(\mathrm{DHA})_{4}\right]$ are given in Supplementary Information.

The solution-state studies of these helicates are very limited due to the insolubility in common organic solvents of $\left[\mathrm{Ti}_{2}\left(\mathrm{~L}^{2}\right)_{2}(\mathrm{Pyr})_{4}\right]$ and $\left[\mathrm{Ti}_{2}\left(\mathrm{~L}^{2}\right)_{2}(\mathrm{MePyr})_{4}\right]$. Nevertheless, $\left[\mathrm{Ti}_{2}\left(\mathrm{~L}^{2}\right)_{2}(\mathrm{DHA})_{4}\right]$ is soluble in $\mathrm{CDCl}_{3}$ but its ${ }^{1} \mathrm{H}$ NMR spectrum is highly complex. However, the DOSY analysis clearly indicates that the dimeric structure of $\left[\mathrm{Ti}_{2}\left(\mathrm{~L}^{2}\right)_{2}(\mathrm{DHA})_{4}\right]$ characterized in the solid-state is maintained in solution. One single diffusion is measured at $\mathrm{D}=440 \pm 40 \mu \mathrm{m}^{2} \cdot \mathrm{s}^{-1}$ which corresponds to a $\mathrm{R}_{\mathrm{h}}$ value of $\mathrm{R}_{\mathrm{h}}=9.2 \pm 0.9 \AA$ matching with the theoretical $R_{h}$ value $\left(R_{h}=9.9 \pm 1 \AA\right)$ evaluated from the crystal structure. ${ }^{14}$ ES-MS analysis 
indicates a peak at $\mathrm{m} / \mathrm{z}=1766.55$ with a isotopic distribution in full accordance with the isotopic pattern simulated for $\left[\mathrm{Ti}_{2}\left(\mathrm{~L}^{2}\right)_{2}(\mathrm{DHA})_{4}\right]+\mathrm{H}^{+}$. Peaks related to $\left[\mathrm{Ti}_{2}\left(\mathrm{~L}^{2}\right)_{2}(\mathrm{DHA})_{3}\right]+\mathrm{H}^{+}$, $\left[\mathrm{Ti}_{2}\left(\mathrm{~L}^{2}\right)_{2}(\mathrm{DHA})_{2}\right]+\mathrm{H}^{+},\left[\mathrm{Ti}_{2}\left(\mathrm{~L}^{2}\right)_{2}(\mathrm{DHA})\right]+\mathrm{H}^{+}$are also detected (see SI).

a)

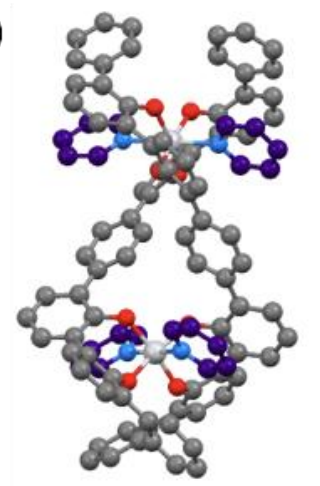

d)

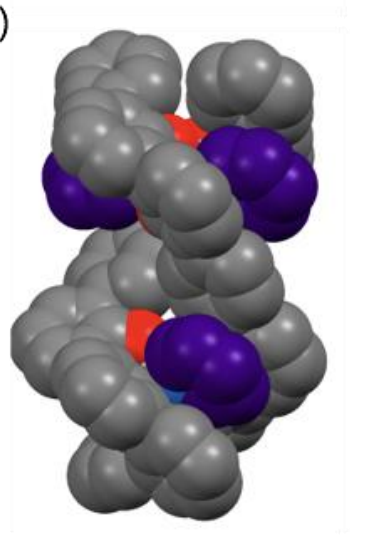

b)

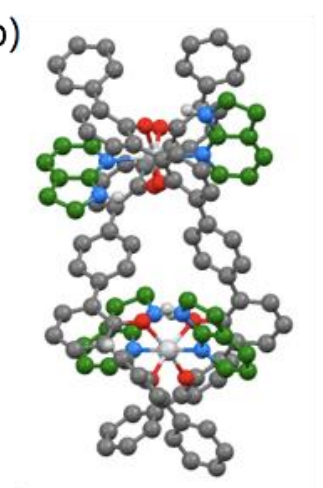

e)

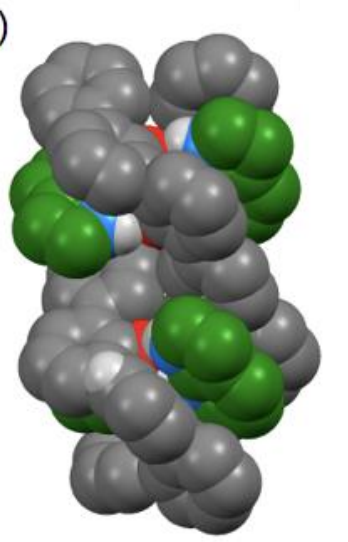

c)

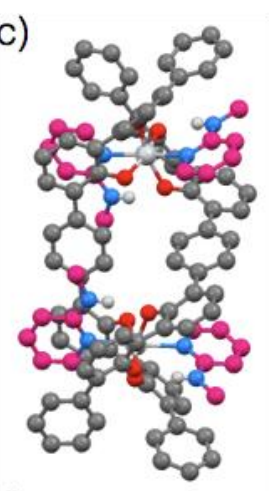

f)

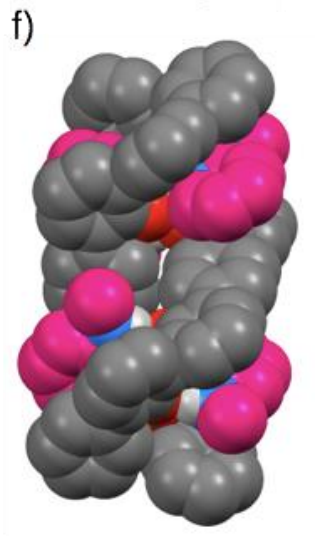

Fig. 5: Crystal structure of $\left[\mathrm{Ti}_{2}\left(\mathrm{~L}^{2}\right)_{2}(\mathrm{Pyr})_{4}\right]$ (a and d), $\left[\mathrm{Ti}_{2}\left(\mathrm{~L}^{2}\right)_{2}(\mathrm{DHA})_{4}\right](\mathrm{b}$ and e) and $\left[\mathrm{Ti}_{2}\left(\mathrm{~L}^{2}\right)_{2}(\mathrm{MePyr})_{4}\right]$ (c and $\mathrm{f}$ ). The $\mathrm{L}^{2}$ carbons are in grey, the oxygens are in red, nitrogen atoms are in blue, the Pyr carbons are in purple, DHA carbons are in green and MePyr are in pink. Hydrogen atoms are omitted for clarity except the $\mathrm{NH}$ hydrogens. Complexes $\left[\mathrm{Ti}_{2}\left(\mathrm{~L}^{2}\right)_{2}(\mathrm{Pyr})_{4}\right]$ and $\left[\mathrm{Ti}_{2}\left(\mathrm{~L}^{2}\right)_{2}(\mathrm{DHA})_{4}\right]$ shown in a, d, b and e adopt a $M$ configuration, whereas complex $\left[\mathrm{Ti}_{2}\left(\mathrm{~L}^{2}\right)_{2}(\mathrm{MePyr})_{4}\right]$ (in c and f) displays a $P$ configuration.

\begin{tabular}{|c|c|c|c|c|c|}
\hline & Ti-Ti $(\AA)$ & Ti-O $(\AA)$ & Ti-N $(\AA)$ & $\begin{array}{l}\underline{\mathrm{NH}} \bullet \bullet \underline{\mathrm{O}} \text { or } \\
\underline{\mathrm{CH}} \bullet \bullet \bullet \underline{\mathrm{O}}(\AA)\end{array}$ & 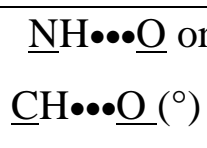 \\
\hline$\left[\mathrm{Ti}_{2}\left(\mathrm{~L}^{2}\right)_{2}(\mathrm{Pyr})_{4}\right]$ & $8.78(5)$ & $1.89 \pm 0.02$ & $2.19 \pm 0.02$ & $3.19 \pm 0.03$ & $118.3 \pm 0.7$ \\
\hline$\left[\mathrm{Ti}_{2}\left(\mathrm{~L}^{2}\right)_{2}(\mathrm{DHA})_{4}\right]$ & $8.87(9)$ & $1.90 \pm 0.02$ & $2.20 \pm 0.01$ & $2.85 \pm 0.04$ & $141.5 \pm 0.5$ \\
\hline
\end{tabular}




\begin{tabular}{|l|c|c|c|c|c|}
\hline$\left[\mathrm{Ti}_{2}\left(\mathrm{~L}^{2}\right)_{2}(\mathrm{MePyr})_{4}\right]$ & $8.80(2)$ & $1.89 \pm 0.01$ & $2.20 \pm 0.01$ & $2.88 \pm 0.05$ & $164.5 \pm 0.4$ \\
\hline
\end{tabular}

Table 2: Selected distances and angles determined in the $\left[\mathrm{Ti}_{2}\left(\mathrm{~L}^{2}\right)_{2}(\mathrm{Pyr})_{4}\right],\left[\mathrm{Ti}_{2}\left(\mathrm{~L}^{2}\right)_{2}(\mathrm{DHA})_{4}\right]$ and $\left[\mathrm{Ti}_{2}\left(\mathrm{~L}^{2}\right)_{2}(\mathrm{MePyr})_{4}\right]$ crystal structures.

\section{Experimental and theoretical evaluation of the hydrogen bond interactions}

Infra-red spectroscopy is a classical technique allowing to evidence hydrogen bonds and to estimate the strength of these interactions. ${ }^{23}$ Thus, the NH stretching of the free ligands MePyr and DHA are compared with the same stretching in the architectures constructed around the trans- $\mathrm{TiO}_{4} \mathrm{~N}_{2}$ core. To disfavour the formation of intermolecular hydrogen bonds, the spectra of compounds MePyr and DHA were recorded for diluted solutions $(\mathrm{c}=0.1 \mathrm{M}$ in toluene). Table 3 contains the frequencies attributed for the NH stretches in the complexes and the free ligands and the spectra are given in SI. Concerning the compounds incorporating the Pyr ligand, a similar study was unsuccessful. Due to the complexity of the spectrum and the weakness of the $\mathrm{CH}$ bands, no usable data is obtained from this study.

\begin{tabular}{|c|c|}
\hline & $\begin{array}{c}\text { NH stretch } \\
\left(\mathrm{cm}^{-1}\right)\end{array}$ \\
\hline $\mathrm{DHA}$ & 3420 \\
\hline$\left[\mathrm{Ti}\left(\mathrm{L}^{1}\right)_{2}(\mathrm{DHA})_{2}\right]$ & 3334 \\
\hline$\left[\mathrm{Ti}_{2}\left(\mathrm{~L}^{2}\right)_{2}(\mathrm{DHA})_{4}\right]$ & 3333 \\
\hline $\mathrm{MePyr}$ & 3422 \\
\hline$\left[\mathrm{Ti}\left(\mathrm{L}^{1}\right)_{2}(\mathrm{MePyr})_{2}\right]$ & 3318 \\
\hline$\left[\mathrm{Ti}{ }_{2}\left(\mathrm{~L}^{2}\right)_{2}(\mathrm{MePyr})_{4}\right]$ & 3319 \\
\hline
\end{tabular}

Table 3: NH stretches in $\mathrm{cm}^{-1}$ recorded for diluted solutions of MePyr and DHA (c $=0.1 \mathrm{M}$ in toluene). $\mathrm{NH}$ stretches in $\mathrm{cm}^{-1}$ recorded for $\left[\mathrm{Ti}\left(\mathrm{L}^{1}\right)_{2}(\mathrm{DHA})_{2}\right],\left[\mathrm{Ti}_{2}\left(\mathrm{~L}^{2}\right)_{2}(\mathrm{DHA})_{4}\right]$, $\left[\mathrm{Ti}\left(\mathrm{L}^{1}\right)_{2}(\mathrm{MePyr})_{2}\right]$ and $\left[\mathrm{Ti}_{2}\left(\mathrm{~L}^{2}\right)_{2}(\mathrm{MePyr})_{4}\right]$.

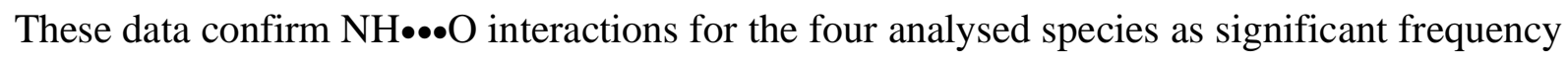
differences are noticed between the $\mathrm{NH}$ stretches in the free ligands and those found in the complexes. Additionally, NH stretch frequencies are identical if the spectra of two complexes incorporating the same nitrogen ligand are compared. Thus, a $\Delta v=104 \mathrm{~cm}^{-1}$ is found between the NH stretch frequencies in free MePyr and its related complexes. In comparison, a less 
pronounced $\Delta v$ value $\left(\Delta v=86 \mathrm{~cm}^{-1}\right)$ is obtained in the case of DHA with $\left[\mathrm{Ti}\left(\mathrm{L}^{1}\right)_{2}(\mathrm{DHA})_{2}\right]$ or $\left[\mathrm{Ti}_{2}\left(\mathrm{~L}^{2}\right)_{2}(\mathrm{DHA})_{4}\right]$ indicating stronger $\mathrm{NH} \bullet \bullet \mathrm{O}$ interactions in $\left[\mathrm{Ti}\left(\mathrm{L}^{1}\right)_{2}(\mathrm{MePyr})_{2}\right]$ and $\left[\mathrm{Ti}_{2}\left(\mathrm{~L}^{2}\right)_{2}(\mathrm{MePyr})_{4}\right]$. The cyclic nature of the DHA ligand is undoubtedly the factor that permits to explain this difference.

In order to quantify the energetic order linked to the intramolecular hydrogen bonding $(\mathrm{CH} \bullet \bullet \bullet \mathrm{O}$ and $\mathrm{NH} \bullet \bullet \bullet \mathrm{O})$ within the complexes, the crystallographic structures are computed with the PACHA (Partial Atomic Charges Analysis) software. ${ }^{20}$ Already, this approach has permitted to evaluate weak interactions in crystalline hydrogen bond networks ${ }^{24}$ or Ti(IV)based helicates. $^{22}$ Therefore, a virtual $360^{\circ}$ rotation of one nitrogen ligand along the Ti-N bond within a complex is performed. These interactions are estimated from two situations. The first one concerns the initial position of the nitrogen ligand within the complex where these interactions represent a maximum and the second results from a position of the nitrogen ligand assuming the suppression of these interactions. Figure 6 shows the energy profiles (self and steric energies) obtained by rotating a Pyr ligand by $360^{\circ}$ along the Ti-N bond in $\left[\mathrm{Ti}\left(\mathrm{L}^{1}\right)_{2}(\mathrm{Pyr})_{2}\right]$. It is worth noting that maxima of both profiles occur for the same angles, a situation typical of a self-energy dominated by repulsive electrostatic interactions. Accordingly, for a given A-B atomic pair with partial charges $\mathrm{q}_{\mathrm{A}}$ and $\mathrm{q}_{\mathrm{B}}$, separated by a distance $\mathrm{R}$, the self-energy profile changes as $\mathrm{SF}=14.4 \cdot \mathrm{q}_{\mathrm{A}} \cdot \mathrm{q}_{\mathrm{B}} / \mathrm{R}$, while the steric energy one will change as $S T=b_{A} \cdot b_{B} \cdot \exp \left[-\left(c_{A}+c_{B}\right) \cdot R\right]$ where $a$ and $b$ are the Gordon-Kim parameters for atoms A and B. It follows that if R goes down, then ST always goes up while SF will decrease if $\mathrm{q}_{\mathrm{A}}$ and $\mathrm{q}_{\mathrm{B}}$ have opposite signs (attraction) and will increase if the two partial charges have the same sign (repulsion). Here, we are clearly in the case where rotation moves atoms having partial charges with the same sign. To estimate the hydrogen bond energy, it is proposed that the hydrogen bond interaction is minimum at the top of self-energy curve. Therefore, the energy changes from $-4112.2 \mathrm{~kJ} \cdot \mathrm{mol}^{-1}$ to $-4106.7 \mathrm{~kJ} . \mathrm{mol}^{-1}$, giving a difference of $5.5 \mathrm{~kJ} . \mathrm{mol}^{-1}$ and thus $2.25 \mathrm{~kJ} . \mathrm{mol}^{-1}$ per $\mathrm{CH} \bullet \bullet \bullet \mathrm{O}$ interaction. An identical approach is employed to estimate the $\mathrm{CH} \bullet \bullet \bullet \mathrm{O}$ interaction in $\left[\mathrm{Ti}_{2}\left(\mathrm{~L}^{2}\right)_{2}(\mathrm{Pyr})_{4}\right]$. The energy profiles (self and steric energies) obtained by rotating a Pyr ring by $360^{\circ}$ along the Ti-N bond in $\left[\mathrm{Ti}_{2}\left(\mathrm{~L}^{2}\right)_{2}(\mathrm{Pyr})_{4}\right]$ is displayed Figure 7 and shows the same repulsive behaviour. Energy of $-8130.7 \mathrm{~kJ} \cdot \mathrm{mol}^{-1}$ is associated to the structure of the complex before the rotation. At the top of the self-energy curve at around $120^{\circ}$, an energy of $-8128.2 \mathrm{~kJ}^{\circ} \mathrm{mol}^{-1}$ is found. Thus, a $\mathrm{CH} \bullet \bullet \bullet \mathrm{O}$ interaction of $1.25 \mathrm{~kJ}^{-\mathrm{mol}^{-1}}$ is estimated in $\left[\mathrm{Ti}_{2}\left(\mathrm{~L}^{2}\right)_{2}(\mathrm{Pyr})_{4}\right]$. 
The same procedure is impossible to apply for the compounds incorporating the DHA ligand, as the rotation of the nitrogen ligand is blocked owing to its highly constrained closed environment. Concerning the two species obtained with MePyr, one investigation is conducted as only the crystal structure of $\left[\mathrm{Ti}_{2}\left(\mathrm{~L}^{2}\right)_{2}(\mathrm{MePyr})_{4}\right]$ was resolved (see figure 8). Albeit the full rotation of the MePyr ligand is not suitable due to its movement blocked, a rotation by $30^{\circ}$ permits to extract useful data. Figure 8 shows that the self-energy and the steric energy have a mirror relationship, meaning that rotation in this case involves atoms bearing partial charges of opposite signs. For the initial structure, energy of $-8224.1 \mathrm{~kJ}^{-\mathrm{mol}^{-1}}$ is calculated. When the MePyr ligand rotates by $30^{\circ}$, the energy associated to this virtual structure is $-8216.0 \mathrm{~kJ} \mathrm{~mol}^{-1}$. Thus, we assume for this position of the MePyr ligand that the inter-ligand $\mathrm{CH} \cdots \mathrm{O}$ and $\mathrm{NH} \cdots \mathrm{O}$ interactions are negligible, which allows evaluation of the $\mathrm{NH} \cdots \mathrm{O}$ interactions. Thus, we assume for this position of the MePyr ligand that the interligand $\mathrm{CH} \bullet \bullet \bullet \mathrm{O}$ and $\mathrm{NH} \bullet \bullet \mathrm{O}$ interactions are negligible which allows the evaluation of the $\mathrm{NH} \bullet \bullet \bullet \mathrm{O}$ interactions. After subtracting the $\mathrm{CH} \bullet \bullet \bullet \mathrm{O}$ energy determined in $\left[\mathrm{Ti}_{2}\left(\mathrm{~L}^{2}\right)_{2}(\mathrm{Pyr})_{4}\right]$ $\left(1.25 \mathrm{~kJ} \cdot \mathrm{mol}^{-1}\right)$ to the energy difference determined between the energy of the initial structure and the energy of the structure when the MePyr ligand rotates by $30^{\circ}$, the $\mathrm{NH} \bullet \bullet \mathrm{O}$ interaction is estimated at $6.8 \mathrm{~kJ} \cdot \mathrm{mol}^{-1}$. This energy value is greatly inferior to the energy usually admitted for hydrogen bonds ${ }^{25}$ that is probably due to the impossibility to estimate the energy for a more pronounced rotation. However, these hydrogen bonds, although calculated to be weak, permit undoubtedly to explain the particular disposition of the nitrogen ligands found in these structures. First, all the structures display the same feature, as the monodentate ligands are always coplanar with neighbouring O-Ti-O alignments. This coplanarity is undoubtedly originated from the $\mathrm{CH} \bullet \bullet \mathrm{O}$ or $\mathrm{NH} \bullet \bullet \mathrm{O}$ interactions. Secondly, beside the argument based on a trans influence to explain the trans isomerism found in all these architectures, we could also highlight that a trans complex maximizes hydrogen bond interactions. Let's take, for example the $\left[\mathrm{Ti}_{2}\left(\mathrm{~L}^{2}\right)_{2}(\mathrm{Pyr})_{4}\right]$ complex. If a cis isomerism is adopted, according the modelled structure shown in Figure 3a, a maximum of three $\mathrm{CH} \bullet \bullet \bullet \mathrm{O}$ interactions between the Pyr ligands and the oxygen atoms could be anticipated. For the trans complex, the $\left[\mathrm{Ti}_{2}\left(\mathrm{~L}^{2}\right)_{2}(\mathrm{Pyr})_{4}\right]$ crystal structure reveals four $\mathrm{CH} \bullet \bullet \bullet \mathrm{O}$ interactions. Therefore, hydrogen bonds are additional contributions permitting to explain the trans isomerism found in our $\mathrm{TiO}_{4} \mathrm{~N}_{2}$-based complexes. 

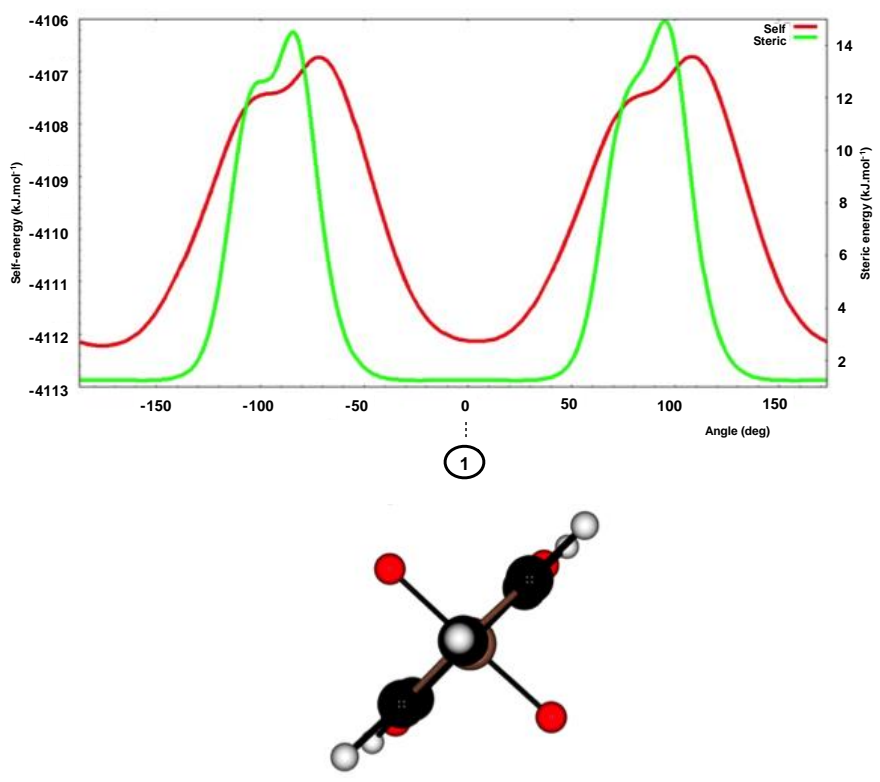

Figure 6: Energy profiles obtained by rotating the Pyr ligand by $360^{\circ}$ along the Ti-N bond in $\left[\mathrm{Ti}\left(\mathrm{L}^{1}\right)_{2}(\mathrm{Pyr})_{2}\right]$. The red curve corresponds to the self-energy, the green curve corresponds to the steric energy. Structure partial view of the Pyr linked to $\mathrm{TiO}_{4}$ before rotation.

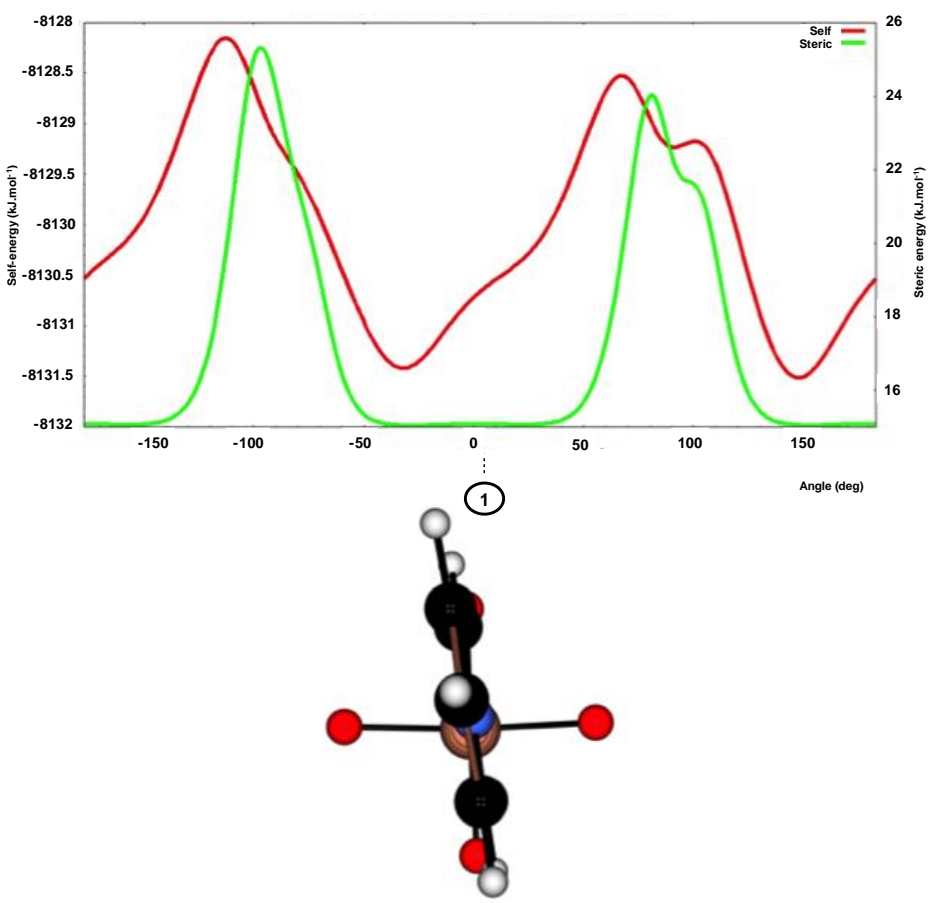

Figure 7: Energy profiles obtained by rotating the Pyr ligand by $360^{\circ}$ along the Ti-N bond in $\left[\mathrm{Ti}_{2}\left(\mathrm{~L}^{2}\right)_{2}(\mathrm{Pyr})_{4}\right]$. The red curve corresponds to the self-energy, the green curve corresponds to the steric energy. Structure partial view of the Pyr linked to $\mathrm{TiO}_{4}$ before rotation. 

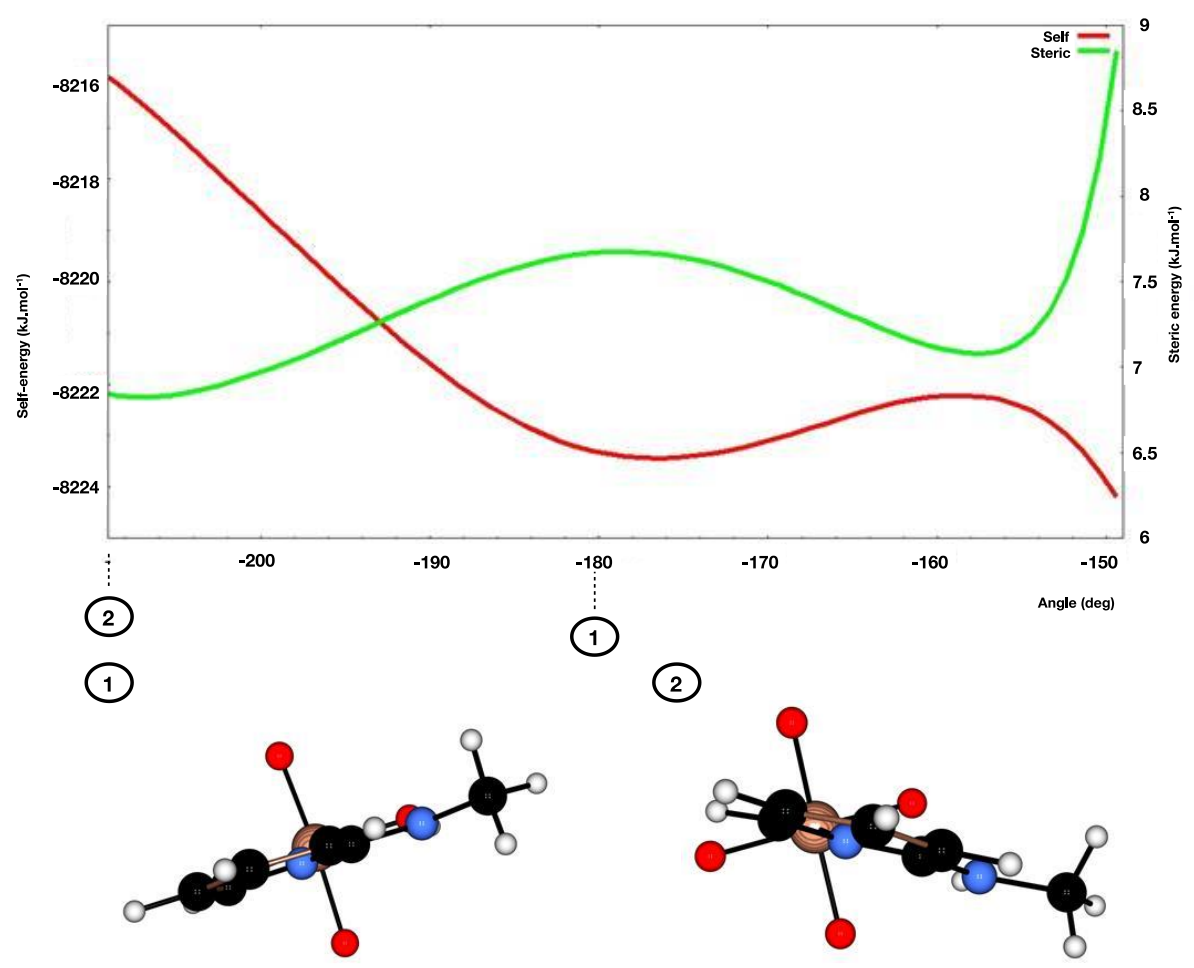

Figure 8: Energy profiles obtained by rotating the MePyr ligand from $-30^{\circ}$ to $+70^{\circ}$ along the Ti-N bond in $\left[\mathrm{Ti}_{2}\left(\mathrm{~L}^{2}\right)_{2}(\mathrm{MePyr})_{4}\right]$. The red curve corresponds to the self-energy, the green curve corresponds to the steric energy. Structure partial view of the MePyr linked to $\mathrm{TiO}_{4}$ before rotation (1) and after rotation (2).

\section{Conclusion}

In conclusion, we described the synthesis of three monomeric species incorporating trans- $\mathrm{TiO}_{4} \mathrm{~N}_{2}$ motifs, in extension this coordination chemistry is able to generate doublestranded helicates through a multi-component self-assembly approach. Two biphenolato fragments and two monodentate nitrogen ligands compose the trans- $\mathrm{TiO}_{4} \mathrm{~N}_{2}$. motif where the preferred trans stereoisomerism is explained conjointly by the trans influence of the nitrogen ligands, disfavouring the cis isomerism. An identical coordination $\mathrm{TiO}_{4} \mathrm{~N}_{2}$ sub-unit is obtained for the three monodentate nitrogen ligands tested viz Pyr, DHA and MePyr. Among the reported architectures, the crystal structure examination, the infra-red spectroscopy analysis as well as a computational study highlight trans $-\mathrm{TiO}_{4} \mathrm{~N}_{2}$ nodes where nitrogen ligand incorporated within the complexes is coordinated to the metal center via a Ti-N coordination bond and additional weak interactions $(\mathrm{CH} \bullet \bullet \bullet \mathrm{O}$ for Pyr and $\mathrm{NH} \bullet \bullet \bullet \mathrm{O}$ for DHA and MePyr). 
Overall, the trans- $\mathrm{TiO}_{4} \mathrm{~N}_{2}$ motif based on two 2,2'-biphenolato fragments and two monodentate nitrogen ligands described in this work represents an attractive node to construct Ti(IV)-based metallo-supramolecular structures and Ti(IV)-based coordination networks. The origin of the higher stability of the trans-isomer has been attributed conjointly to an electronic effect favouring the isomer showing the smallest trans-influence and to a trans-isomerism that maximizes $\mathrm{CH} \bullet \bullet \bullet \mathrm{O}$ or $\mathrm{NH} \bullet \bullet \bullet$ interactions compared to cis-isomerism. Relative energies of $\mathrm{CH} \bullet \bullet \bullet \mathrm{O}$ and $\mathrm{NH} \bullet \bullet \mathrm{O}$ weak interactions have been quantified, leading to values lower than $\mathrm{k}_{\mathrm{B}} \mathrm{T}=2.5 \mathrm{~kJ} \cdot \mathrm{mol}^{-1}\left(\mathrm{~T}=25^{\circ} \mathrm{C}\right)$ for $\mathrm{CH} \bullet \bullet \bullet \mathrm{O}$ interactions and about $3 \mathrm{k}_{\mathrm{B}} \mathrm{T}$ for $\mathrm{NH} \bullet \bullet \bullet \mathrm{O}$ interactions.

\section{Acknowlegments}

We warmly thank Dr. Alain Chaumont for DFT calculation and the HPC centre of the University of Strasbourg for computer resources. This project was supported by the Centre National de la Recherche Scientifique (CNRS, France), the Laboratory of Excellence (LABEX) "Chemistry of Complex Systems" (scholarship to G.K.).

\section{Experimental part}

The following commercial reagents were used as received: Pyr (99.5\%, extra dry, Acros), MePyr (Aldrich) and DHA (Aldrich). The solvents were dried over molecular sieve before use. Complex cis-[Ti( $\left.\left(\mathrm{L}^{1}\right)_{2}\left(\mathrm{HO}{ }^{i} \mathrm{Pr}\right)_{2}\right]^{26}$ and ligand $\mathrm{L}^{2}-\mathrm{H}_{4}{ }^{27}$ were synthesized following reported procedures.

Bruker Avance-500 and Avance-600 spectrometers were used for solution NMR analyses performed at $25^{\circ} \mathrm{C}$. NMR samples were prepared under argon. Deuterated solvents for ${ }^{1} \mathrm{H}$ NMR analysis were dried over molecular sieves before use. ${ }^{1} \mathrm{H}$ NMR spectra were recorded at $500.13 \mathrm{MHz}$ and referenced to $\mathrm{SiMe}_{4} .{ }^{13} \mathrm{C}\left\{{ }^{1} \mathrm{H}\right\}$ NMR spectra (broadband decoupled) were recorded at $125.77 \mathrm{MHz}$ and referenced to $\mathrm{SiMe}_{4}$. Chemical shifts are reported in ppm and coupling constants in $\mathrm{Hz}$; the latter are proton-proton coupling constants. Multiplicity: $\mathrm{s}=$ singlet, $\mathrm{d}=$ doublet, $\mathrm{t}=$ apparent triplet, $\mathrm{m}=$ multiplet. The ${ }^{13} \mathrm{C}\left\{{ }^{1} \mathrm{H}\right\}$ signals are singlets. DOSY measurements were performed at $600.13 \mathrm{MHz}$ with a $5 \mathrm{~mm}{ }^{1} \mathrm{H} / \mathrm{X}$ z-gradient $\mathrm{BBI}$ 
probe and applying a PFGSTE pulse sequence using bipolar gradients. DOSY spectra were generated with the DOSY module of NMRNotebook ${ }^{\mathrm{TM}}$ software, via maximum entropy and inverse Laplace transform calculation. Infrared (IR) spectra were recorded with a Shimadzu FTIR-8400S spectrometer. The band intensity are indicated as follows, (s) for strong, (m) for medium and (w) for weak. Electrospray analyses were performed on a MicroTOF (Bruker) apparatus equipped with an Electrospray (ES) source. The elemental analyses were performed on a Flash 2000 apparatus (ThermoFischer Scientific) for C, H, and N elements.

The X-Ray diffraction data were collected at $173 \mathrm{~K}$ on a Bruker SMART CCD diffractometer with MoK $\alpha$ radiation $(\lambda=0.71073 \AA)$. The diffraction data were corrected for absorption using the SADABS program. ${ }^{28}$ The structures were solved using SHELXS97 ${ }^{29}$ and refined by full matrix least-squares on F2 using SHELXL-2014 ${ }^{30}$ in the anisotropic approximation for all non-hydrogen atoms. The hydrogen atoms were introduced at calculated positions and not refined (riding model). Density functional theory (DFT) calculations on the trans$\left[\mathrm{Ti}\left(\mathrm{L}^{1}\right)_{2}(\mathrm{Pyr})_{2}\right]$ and cis-[Ti( $\left.\left(\mathrm{L}^{1}\right)_{2}(\mathrm{Pyr})_{2}\right]$ complexes have been performed with the Gaussian09 Revision D01 package. ${ }^{16}$ Hybrid exchange correlation functional B3LYP using the cc-pVTZ basis set with an ultrafine grid was used for the calculations. ${ }^{31}$

General procedure for the synthesis of monomeric species. Under Ar protection (glovebag), vapors of $n$-pentane or diethyl ether was allowed to slowly diffuse into a solution of dry $\mathrm{CHCl}_{3}(1.5 \mathrm{~mL})$ containing the nitrogen monodentate ligand (1 equiv.) and the cis$\left[\mathrm{Ti}\left(\mathrm{L}^{1}\right)_{2}\left(\mathrm{HO}^{i} \mathrm{Pr}\right)_{2}\right]$ complex $(10 \mathrm{mg}, 11.9 \square \mathrm{mol})$. Crystals were formed after 48 hours and isolated by filtration.

[Ti( $\left.\left.\mathbf{L}^{\mathbf{1}}\right)_{2}(\mathbf{P y r})_{2}\right]$. Crystals were obtained from $\mathrm{CHCl}_{3} /$ ether. Yield: 66\%. NMR analysis revealed an important amount of free $\mathrm{L}^{1} \mathrm{H}_{2}$ and pyridine ligands originated from the degradation of $\left[\mathrm{Ti}\left(\mathrm{L}^{1}\right)_{2}(\mathrm{Pyr})_{2}\right]$ upon dissolution. ${ }^{1} \mathrm{H}$ NMR $\left(\mathrm{CDCl}_{3}, 500 \mathrm{MHz} \square \square \square \delta \square 7.48\right.$ (d, $\left.{ }^{3} J=5.1 \mathrm{~Hz}, 4 \mathrm{H}\right), 7.42\left(\mathrm{tt},{ }^{3} J=7.6 \mathrm{~Hz},{ }^{4} J=1.4 \mathrm{~Hz}, 2 \mathrm{H}\right), 7.32\left(\mathrm{dd},{ }^{3} J=7.3 \mathrm{~Hz},{ }^{4} J=1.0 \mathrm{~Hz}\right.$, $8 \mathrm{H}), 7.24\left(\mathrm{dd},{ }^{3} J=7.6 \mathrm{~Hz},{ }^{4} \mathrm{~J}=1.7 \mathrm{~Hz}, 4 \mathrm{H}\right), 7.19\left(\mathrm{t},{ }^{3} \mathrm{~J}=7.6 \mathrm{~Hz}, 8 \mathrm{H}\right), 7.09\left(\mathrm{t},{ }^{3} \mathrm{~J}=7.3 \mathrm{~Hz}\right.$, $4 \mathrm{H}), 6.93\left(\mathrm{dd},{ }^{3} \mathrm{~J}=7.7 \mathrm{~Hz},{ }^{4} \mathrm{~J}=2.0 \mathrm{~Hz}, 4 \mathrm{H}\right), 6.81\left(\mathrm{t},{ }^{3} \mathrm{~J}=7.6 \mathrm{~Hz}, 4 \mathrm{H}\right), 6.41(\mathrm{~m}, 4 \mathrm{H}) .{ }^{13} \mathrm{C}\left\{{ }^{1} \mathrm{H}\right\}$ NMR ( $\left.\mathrm{CDCl}_{3}, 125 \mathrm{MHz}\right): \delta \square 161.29,147.42,138.96,136.82,131.48,131.16,129.87,129.24$, 
128.56, 126.97, 126.17, 123.03, 120.61. ${ }^{1} \mathrm{H}$ NMR DOSY $\left(\mathrm{CD}_{2} \mathrm{Cl}_{2}, 600 \mathrm{MHz}\right): D=660 \mu \mathrm{m}^{2} . \mathrm{s}^{-}$ 1. MS (ESI): $m / z$ calcd for $\left[\mathrm{Ti}\left(\mathrm{L}^{1}\right)_{2}+\mathrm{Na}\right]^{+}$743.17, found 743.17. Infrared $\left(\mathrm{cm}^{-1}\right): 3363(\mathrm{w})$, 3056 (w), 2921 (w), 1604 (w), 1499 (w), 1419 (w), 1401 (w), 1395 (s), 1244 (s), 1083 (m), 1045 (m), 863 (s), 749 (s), 695 (s), 625 (s). Anal. Calcd. for $\mathrm{C}_{58} \mathrm{H}_{42} \mathrm{~N}_{2} \mathrm{O}_{4} \mathrm{Ti} \cdot 3 / 2 \mathrm{Et}_{2} \mathrm{O}$ : C, 77.64; N, 2.83; H, 5.80. Found: C, 77.47; N, 2.80; H, 5.71. CCDC 1829310.

[ $\left.\mathbf{T i}\left(\mathbf{L}^{1}\right)_{2}(\mathbf{D H A})_{2}\right]$. Crystals were obtained from $\mathrm{CHCl}_{3} / \mathrm{Et}_{2} \mathrm{O}$. Yield: $90 \%$. Due to the presence in solution of some $\mathrm{L}^{1}-\mathrm{H}_{2}$ and DHA generated from the degradation of $\left[\mathrm{Ti}\left(\mathrm{L}^{1}\right)_{2}(\mathrm{DHA})_{2}\right]$ upon dissolution, an accurate integration of all signals belonging to the complex was not possible. ${ }^{1} \mathrm{H}$ NMR $\left(\mathrm{CDCl}_{3}, 600 \mathrm{MHz}\right)$, selected data: $\delta \square 7.57-7.45(\mathrm{~m}), 7.40-7.04(\mathrm{~m}), 7.01$ (dd, ${ }^{3} J=$ $\left.7.6 \mathrm{~Hz},{ }^{4} J=1.9 \mathrm{~Hz}, 2 \mathrm{H}\right), 6.98\left(\mathrm{dd},{ }^{3} J=7.6 \mathrm{~Hz},{ }^{4} \mathrm{~J}=1.8 \mathrm{~Hz}, 2 \mathrm{H}\right), 6.85\left(\mathrm{t},{ }^{3} \mathrm{~J}=7.6 \mathrm{~Hz}, 2 \mathrm{H}\right)$, $6.83\left(\mathrm{t},{ }^{3} J=7.6 \mathrm{~Hz}, 2 \mathrm{H}\right), 6.82\left(\mathrm{t},{ }^{3} J=7.6 \mathrm{~Hz}, 2 \mathrm{H}\right), 6.80\left(\mathrm{t},{ }^{3} J=7.6 \mathrm{~Hz}, 2 \mathrm{H}\right), 6.70\left(\mathrm{~d},{ }^{3} J=6.7\right.$ $\mathrm{Hz}, 4 \mathrm{H}), 6.64\left(\mathrm{~d},{ }^{3} J=6.0 \mathrm{~Hz}, 4 \mathrm{H}\right), 5.70(\mathrm{~s}, 2 \mathrm{H}), 5.68(\mathrm{~s}, 2 \mathrm{H}), 5.13\left(\mathrm{t},{ }^{3} J=6.5 \mathrm{~Hz}, 2 \mathrm{H}\right), 5.12(\mathrm{t}$, $\left.{ }^{3} J=6.6 \mathrm{~Hz}, 2 \mathrm{H}\right), 2.69-2.47(\mathrm{~m}, 16 \mathrm{H}) .{ }^{13} \mathrm{C}\left\{{ }^{1} \mathrm{H}\right\} \mathrm{NMR}\left(\mathrm{CDCl}_{3}, 125 \mathrm{MHz} \square \square \square \delta \square 161.80\right.$, $161.21,161.08,160.52,160.40,160.36,142.52,142.48,139.90,139.83,139.08,139.03$, $132.28,132.04,131.31,131.25,131.24,131.02,130.91,130.85,130.66,130.35,130.11$, $129.87,129.81,129.79,129.71,129.48,129.42,129.38,129.22,129.20,128.78,128.51$, $127.50,127.29$, 127.27, 127.25, 127.04, 126.69, 126.16, 126.07, 124.01, 123.96, 121.32, 121.23, 120.96, 120.88, 109.63, 109.57, 43.26, 43.24, 26.13, 26.11. ${ }^{1} \mathrm{H}$ NMR DOSY $\left(\mathrm{CD}_{2} \mathrm{Cl}_{2}\right.$, $600 \mathrm{MHz}): D=650 \mu \mathrm{m}^{2} . \mathrm{s}^{-1}$. MS (ESI): $m / z$ calcd for $\left[\left[\mathrm{Ti}^{2}\left(\mathrm{~L}^{1}\right)_{2}(\mathrm{DHA})\right]+\mathrm{H}\right]^{+} 841.25$, found 841.25. Infrared (cm $\left.{ }^{-1}\right): 3349$ (w), 3054 (w), 3039 (w), 1629 (w), 1597 (m), 1516 (m), 1499 (m), 1414 (m), 1397 (s), 1325 (m), 1279 (m), 1227 (s), 1087 (m), 859 (s), 749 (s), 692 (s), 688 (s), 626 (s), 605 (s). Anal. Calcd. for $\mathrm{C}_{62} \mathrm{H}_{48} \mathrm{~N}_{4} \mathrm{O}_{4} \mathrm{Ti}_{\bullet} \bullet \frac{1}{2} \mathrm{Et}_{2} \mathrm{O}: \mathrm{C}, 77.02 ; \mathrm{N}, 5.61 ; \mathrm{H}, 5.35$. Found: C, 76.97; N, 5.75; H, 5.13. CCDC 1829314.

[Ti( $\left.\mathbf{L}^{1}\right)_{2}$ (MePyr $)_{2}$ ]. [Ti( $\left.\mathrm{L}^{1}\right)_{2}(\mathrm{MePyr})_{2}$ ] crystals were obtained from $\mathrm{CHCl}_{3} / \mathrm{Et}_{2} \mathrm{O}$. Yield: $52 \%$. Due to the presence in solution of some $\mathrm{L}^{1}-\mathrm{H}_{2}$ and MePyr generated from the degradation of $\left[\mathrm{Ti}\left(\mathrm{L}^{1}\right)_{2}(\mathrm{MePyr})_{2}\right]$ upon dissolution, an accurate integration of all signals belonging to the complex was not possible. ${ }^{1} \mathrm{H}$ NMR $\left(\mathrm{CDCl}_{3}, 500 \mathrm{MHz}\right)$, selected data $\square \square \delta \square 7.50-7.02(\mathrm{~m})$, $6.96\left(\mathrm{dd},{ }^{3} \mathrm{~J}=7.6 \mathrm{~Hz},{ }^{4} \mathrm{~J}=1.8 \mathrm{~Hz}, 2 \mathrm{H}\right), 6.95\left(\mathrm{dd},{ }^{3} \mathrm{~J}=7.7 \mathrm{~Hz},{ }^{4} \mathrm{~J}=1.8 \mathrm{~Hz}, 2 \mathrm{H}\right), 6.83\left(\mathrm{t},{ }^{3} \mathrm{~J}=\right.$ $7.6 \mathrm{~Hz}, 2 \mathrm{H}), 6.82\left(\mathrm{t},{ }^{3} J=7.6 \mathrm{~Hz}, 2 \mathrm{H}\right), 6.80\left(\mathrm{t},{ }^{3} J=7.6 \mathrm{~Hz}, 2 \mathrm{H}\right), 6.79\left(\mathrm{t},{ }^{3} J=7.6 \mathrm{~Hz}, 2 \mathrm{H}\right), 6.58$ $\left(\mathrm{q},{ }^{3} J=4.6 \mathrm{~Hz}, 2 \mathrm{H}\right), 6.57\left(\mathrm{q},{ }^{3} J=4.6 \mathrm{~Hz}, 2 \mathrm{H}\right), 5.69\left(\mathrm{~d},{ }^{3} J=5.2 \mathrm{~Hz}, 2 \mathrm{H}\right), 5.67\left(\mathrm{~d},{ }^{3} J=5.2 \mathrm{~Hz}\right.$, $2 \mathrm{H}), 5.26-5.22(\mathrm{~m}, 4 \mathrm{H}), 1.71\left(\mathrm{~d},{ }^{3} \mathrm{~J}=4.8 \mathrm{~Hz}, 6 \mathrm{H}\right), 1.70\left(\mathrm{~d},{ }^{3} \mathrm{~J}=4.9 \mathrm{~Hz}, 6 \mathrm{H}\right) .{ }^{13} \mathrm{C}\left\{{ }^{1} \mathrm{H}\right\} \mathrm{NMR}$ $\left(\mathrm{CDCl}_{3}, 125 \mathrm{MHz} \square \square \square \delta \square 161.32,160.88,160.72,155.13,156.07,156.05,146.84,146.71\right.$, $139.49,139.35,138.92,138.82,137.67,137.64,131.54,131.39,130.91,130.84,130.78$, 
$130.74,130.70,130.50,130.20,130.15,129.91,129.88,129.71,129.45,129.43,129.40$, 129.32, 129.30, 128.82, 128.37, 127.21 (2 superimposed signals), 126.87 (2 superimposed signals), 126.24, 126.20, 125.89, 125.83, 121.38, 121.19, 121.13, 120.94, 109.72, 109.70, 105.11, 105.04, 28.90, 28.87. $\square \mathrm{MS}(\mathrm{ESI}): \mathrm{m} / \mathrm{z}$ calcd for $\left[\left[\mathrm{Ti}\left(\mathrm{L}^{1}\right)_{2}(\mathrm{MePyr})\right]+\mathrm{H}\right]^{+}$829.25, found 829.25. Infrared ( $\left.\mathrm{cm}^{-1}\right)$ : $3326(\mathrm{w}), 3057(\mathrm{w}), 1618(\mathrm{~m}), 1587(\mathrm{~m}), 1540(\mathrm{w}), 1483(\mathrm{~m})$, 1414 (s), 1396 (s), 1336 (s), 1335 (s), 1085 (m), 996 (w), 860 (s), 747 (s), 694 (s), 691 (s), 626 (s), 605 (s). Anal. Calcd. for $\mathrm{C}_{60} \mathrm{H}_{48} \mathrm{~N}_{4} \mathrm{O}_{4} \mathrm{Ti}^{\circ} 1 / 4 \mathrm{CHCl}_{3}$ : C, 74.85; N, 5.80; H, 5.03; found: $\mathrm{C}$, $75.00 ; \mathrm{N}, 5.71 ; \mathrm{H}, 5.21$.

General procedure for the helicates synthesis. In a sealed vial, pyridine or pyridine derivative compounds (1 equiv.) and $\mathrm{L}^{2}-\mathrm{H}_{4}$ (1 equiv.) was dissolved in dry toluene $(1.5 \mathrm{~mL})$ under argon protection. Then, titanium (IV) isopropoxide (5 $\square \mathrm{L}, 1$ equiv.) was added leading to an orange solution. After, the solution was heated at $100^{\circ} \mathrm{C}$ for $24 \mathrm{~h}$. Crystals obtained were separated by filtration.

[Ti2 $\left.\left(\mathbf{L}^{2}\right)_{2}(\mathbf{P y r})_{4}\right]$. Crystals were obtained from toluene after $24 \mathrm{~h}$ at $100{ }^{\circ} \mathrm{C}$. Yield: $24 \%$. The complex could not be analyzed by NMR due to poor solubility in common deuterated solvents. Crystals suitable from X-ray analysis were produced from $\mathrm{CHCl}_{3} / n$-pentane (R.T.). Infrared (cm-1): 3060 (w), 2952 (w), 1607 (w), 1446 (m), 1394 (m), 1230 (s), 1089 (m), 1069 (m), 1043 (m), 853 (s), 785 (m), 750 (s), 692 (s), 668 (s), 641 (m), 625 (s), 613 (s), 575 (m), 479 (s). Anal. Calcd. for $\mathrm{C}_{104} \mathrm{H}_{72} \mathrm{~N}_{4} \mathrm{O}_{8} \mathrm{Ti}_{2} \bullet 5 / 2 \mathrm{CHCl}_{3}: \mathrm{C}, 67.33 ; \mathrm{N}, 2.95 ; \mathrm{H}, 3.95$. Found $\mathrm{C}$, 67.54; N, 3.08; H, 4.15. CCDC 1829312.

[Ti $\left.\mathbf{T i}_{2}\left(\mathbf{L}^{2}\right)_{2}(\mathbf{D H A})_{4}\right]$. Crystals were obtained from toluene after 18 hours at $100^{\circ} \mathrm{C}$. Yield: $27 \%$. ${ }^{1} \mathrm{H}$ NMR DOSY $\left(\mathrm{CD}_{2} \mathrm{Cl}_{2}, 600 \mathrm{MHz}\right): D=440 \mu \mathrm{m}^{2} \cdot \mathrm{s}^{-1}$. MS (ESI): $\mathrm{m} / \mathrm{z}$ calcd for $\left.\left[\mathrm{Ti}\left(\mathrm{L}^{2}\right)_{2}(\mathrm{DHA})_{4}\right]+\mathrm{H}\right]^{+} 1766.55$ found 1766.55 ; calcd for $\left.\left[\mathrm{Ti}\left(\mathrm{L}^{2}\right)_{2}(\mathrm{DHA})_{3}\right]+\mathrm{H}\right]^{+} 1646.48$ found 1646.48; calcd for $\left.\left[\mathrm{Ti}\left(\mathrm{L}^{2}\right)_{2}(\mathrm{DHA})_{2}\right]+\mathrm{H}\right]^{+} 1525.41$ found 1525.41 ; calcd for $\left.\left[\mathrm{Ti}\left(\mathrm{L}^{2}\right)_{2}(\mathrm{DHA})\right]+\mathrm{H}\right]^{+} 1405.34$ found 1405.34. Infrared $\left(\mathrm{cm}^{-1}\right): 3349(\mathrm{w}), 3063(\mathrm{w}), 1662(\mathrm{w})$, 1629 (w), 1595 (m), 1516 (m), 1398 (m), 1325 (m), 1281 (m), 1239 (s), 1089 (m), 860 (s), 752 (s), 695 (s), 664 (s), 606 (s). Anal. Calcd. for $\mathrm{C}_{112} \mathrm{H}_{84} \mathrm{~N}_{8} \mathrm{O}_{8} \mathrm{Ti}_{2} \bullet 3 / 2 \mathrm{CDCl}_{3}: \mathrm{C}, 70.10$; N, 5.76; H, 4.43. Found C, 69.80; N, 5.52; H, 4.88 (crystals had been first dissolved in $\mathrm{CDCl}_{3}$ for NMR analysis). CCDC 1829313.

$\left[\mathbf{T i}_{2}\left(\mathbf{L}^{2}\right)_{2}(\mathbf{M e P y r})_{4}\right]$. Crystals were obtained from toluene after 24 hours at $100^{\circ} \mathrm{C}$. Yield: 22\%. MS (ESI): $m / z$ calcd for $\left[\mathrm{Ti}_{2}\left(\mathrm{~L}^{2}\right)_{2}+\mathrm{Na}\right]^{+}$1307.25, found 1307.26; calcd for 
$\left[\mathrm{Ti}_{2}\left(\mathrm{~L}^{2}\right)_{2}(\mathrm{MePyr})+\mathrm{H}\right]^{+}$1393.34, found 1393.34. Infrared $\left(\mathrm{cm}^{-1}\right): 3321(\mathrm{w}), 3065(\mathrm{w}), 1619$ (m), 1588 (m), 1544 (w), 1485 (w), 1418 (m), 1398 (s), 1225 (s), 1170 (m), 1085 (m), 998 (m), 854 (s), 756 (s), 694 (s), 665 (s), 605 (s). Anal. Calcd. for $\mathrm{C}_{108} \mathrm{H}_{84} \mathrm{~N}_{8} \mathrm{O}_{8} \mathrm{Ti}_{2} \bullet$ toluene: C, 76.32; N, 6.19; H, 5.12; Found C, 75.88; N, 6.24; H, 5.16. CCDC 1829311. 


\begin{tabular}{|c|c|c|c|c|c|}
\hline & {$\left[\mathrm{Ti}\left(\mathrm{L}^{1}\right)_{2}(\mathrm{Py})_{2}\right]$} & {$\left[\operatorname{Ti}\left(\mathrm{L}^{1}\right)_{2}(\mathrm{DHA})_{2}\right]$} & {$\left[\mathrm{Ti}_{2}\left(\mathrm{~L}^{2}\right)_{2}(\mathrm{Py})_{4}\right]$} & {$\left[\mathrm{Ti}_{2}\left(\mathrm{~L}^{2}\right)_{2}(\mathrm{MePy})_{4}\right]$} & {$\left[\mathrm{Ti}_{2}\left(\mathrm{~L}^{2}\right)_{2}(\mathrm{DHA})_{4}\right]$} \\
\hline Formula & $\mathrm{C}_{62} \mathrm{H}_{52} \mathrm{~N}_{2} \mathrm{O}_{5} \mathrm{Ti}$ & $\mathrm{C}_{62} \mathrm{H}_{48} \mathrm{~N}_{4} \mathrm{O}_{4} \mathrm{Ti}$ & $\mathrm{C}_{104} \mathrm{H}_{72} \mathrm{~N}_{4} \mathrm{O}_{8} \mathrm{Ti}_{2}, 3 \mathrm{CHCl}_{3}$ & $\begin{array}{l}\mathrm{C}_{108} \mathrm{H}_{84} \mathrm{~N}_{8} \mathrm{O}_{8} \\
\mathrm{Ti}_{2}, \mathrm{C}_{7} \mathrm{H}_{8}\end{array}$ & $\begin{array}{l}\mathrm{C}_{112} \mathrm{H}_{84} \mathrm{~N}_{8} \mathrm{O}_{8} \mathrm{Ti}_{2}, \\
\mathrm{C}_{7} \mathrm{H}_{8}\end{array}$ \\
\hline FW & 952.95 & 959.93 & 1959.56 & 1809.76 & 1857.80 \\
\hline $\begin{array}{l}\text { Crystal } \\
\text { system }\end{array}$ & Triclinic & Monoclinic & Triclinic & Triclinic & Monoclinic \\
\hline $\begin{array}{l}\text { Space } \\
\text { group }\end{array}$ & $P-1$ & $P 121 / \mathrm{c} 1$ & $P-1$ & $P-1$ & $C 12 / \mathrm{c} 1$ \\
\hline$a[\AA]$ & $11.6088(5)$ & $20.2023(10)$ & $13.1680(10)$ & $10.8958(6)$ & $50.172(4)$ \\
\hline$b[\AA]$ & $12.5943(4)$ & $14.2491(9)$ & 19.081(2) & $19.0728(16)$ & $10.9727(8)$ \\
\hline$c[\AA]$ & $17.0245(6)$ & $17.1910(10)$ & $21.467(2)$ & $22.9783(12)$ & $37.185(3)$ \\
\hline$\alpha\left[^{\circ}\right]$ & $83.344(2)$ & 90 & $66.712(3)$ & $105.583(5)$ & 90 \\
\hline$\beta\left[^{\circ}\right]$ & $80.188(2)$ & $106.517(2)$ & $75.515(3)$ & 94.894(3) & $117.267(2)$ \\
\hline$\gamma\left[{ }^{\circ}\right]$ & $88.761(2)$ & 90 & $82.992(3)$ & 98.119(5) & 90 \\
\hline $\begin{array}{l}\text { Volume } \\
{\left[\AA^{3}\right]}\end{array}$ & 2436.12(16) & $4744.5(5)$ & $4795.2(8)$ & $4515.4(5)$ & 18196.(3) \\
\hline $\mathrm{Z}$ & 2 & 4 & 2 & 2 & 8 \\
\hline$T[\mathrm{~K}]$ & $173(2)$ & $173(2)$ & $173(2)$ & $173(2)$ & $173(2)$ \\
\hline $\begin{array}{l}\text { Ind. refls. } \\
\text { (Rint) }\end{array}$ & $\begin{array}{l}10538 \\
(0.0343)\end{array}$ & $10979(0.0674)$ & $25578(0.0440)$ & $23570(0.0529)$ & $19360(0.1003)$ \\
\hline Refls. coll. & 106848 & 46708 & 25578 & 135066 & 39320 \\
\hline $\begin{array}{l}R_{l}(\mathrm{I}> \\
2 \sigma(\mathrm{I}))^{\mathrm{a}}\end{array}$ & 0.0361 & 0.0753 & 0.0824 & 0.0491 & 0.0743 \\
\hline $\begin{array}{l}w R_{2}(\mathrm{I}> \\
2 \sigma(\mathrm{I}))^{\mathrm{a}}\end{array}$ & 0.0885 & 0.1732 & 0.2384 & 0.1158 & 0.1440 \\
\hline $\begin{array}{l}R_{I} \text { (all } \\
\text { data) }\end{array}$ & 0.0454 & 0.1123 & 0.1466 & 0.0918 & 0.1723 \\
\hline $\begin{array}{l}w R_{2} \text { (all } \\
\text { data) })^{\mathrm{a}}\end{array}$ & 0.0941 & 0.1886 & 0.2628 & 0.1372 & 0.1880 \\
\hline GOF & 1.026 & 1.034 & 1.039 & 1.027 & 1.0569 \\
\hline
\end{tabular}

\section{References}

${ }^{1}$ W. Wang, Y.-X. Wang and H.-B. Yang, Chem. Soc. Rev., 2016, 45, 2656-2693; T. R. Cook and P. J. Stang, Chem. Rev., 2015, 115, 7001-7045.

${ }^{2}$ M. Albrecht, Chem. Rev. 2001, 101, 3457-3498; C. Piguet, G. Bernardinelli, G. Hopfgartner, Chem. Rev., 1997, 97, 2005-2062. 
${ }^{3}$ S. Durot, J. Taesch, and V. Heitz, Chem. Rev., 2014, 114, 8542-8578; M. Han, D. M. Engelhard and G. H. Clever, Chem. Soc. Rev., 2014, 43, 1848-1860; H. Amouri, C. Desmarets, and J. Moussa, Chem. Rev., 2012, 112, 2015-2041.

${ }^{4}$ S. J. Lee and J. T. Hupp, Coord. Chem. Rev., 2006, 250, 1710-1723.

${ }^{5}$ Q.-F. Sun, J. Iwasa, D. Ogawa, Y. Ishido, S. Sato, T. Ozeki, Y. Sei, K. Yamaguchi and M. Fujita, Science, 2010, 328, 1144-1147.

${ }^{6}$ A.-M. Stadler, Eur. J. Inorg. Chem., 2009, 32, 4751-4770.

${ }^{7}$ J.-F. Ayme, J. E. Beves, C. J. Campbell and D. A. Leigh, Chem. Soc. Rev., 2013, 42, 17001712; S. Prusty, S. Krishnaswamy, S. Bandi, B. Chandrika, J. Luo, J. S. McIndoe, G. S. Hanan and D. K. Chand, Chem. Eur. J., 2015, 21, 1 - 15; M. Fujita, Acc. Chem. Res., 1999, 32, 53-61.

${ }^{8}$ R. Chakrabarty, P. S. Mukherjee, and P. J. Stang, Chem. Rev., 2011, 111, 6810-6918 ; M. Fujita, M. Tominaga, A. Hori and B. Therrien, Acc. Chem. Res., 2005, 38, 369-378.

${ }^{9}$ M. Albrecht and B. A. Stöckel, Synlett, 2011, 121-123 ; R. M. Yeh, J. Xu, G. Seeber and K. N. Raymond, Inorg. Chem. 2005, 44, 6228-6239; M. Albrecht, M. Napp, M. Schneider, P. Weis and R. Fröhlich, Chem. Eur. J., 2001, 7, 3966-3975; C. Brückner, R. E. Powers and K. N. Raymond, Angew. Chem. Int. Ed., 1998, 37, 1837-1839.

${ }^{10}$ C. Diebold, P. Mobian, C. Huguenard, L. Allouche and M. Henry, Dalton Trans., 2009, 10178-10180.

${ }^{11}$ D. M. Weekes, C. Diebold, P. Mobian, C. Huguenard, L. Allouche and M. Henry, Chem.Eur. J., 2014, 20, 5092-5101; C. Diebold, P. Mobian, C. Huguenard, L. Allouche and M. Henry, Inorg. Chem., 2010, 49, 6369-6371.

${ }^{12}$ D. M. Weekes, N. Baradel, N. Kyritsakas, P. Mobian and M. Henry, Eur. J. Inorg. Chem., 2012, 34, 5701-5713.

${ }^{13}$ P. Mobian, N. Baradel, N. Kyritsakas, G. Khalil and M. Henry, Chem.-Eur. J., 2015, 21, 2435-2441.

${ }^{14}$ These values are estimated according to A. Gavezotti, J. Am. Chem. Soc., 1983, 105, 52205225. Van der Waals radii used: $\mathrm{H}=1.2 \AA, \mathrm{C}=1.7 \AA, \mathrm{N}=1.55 \AA, \mathrm{O}=1.52 \AA$ (see A.

Bondi, J. Phys. Chem. 1964, 68, 441-451) and Ti = 1.45 А (assumed).

${ }^{15}$ C. Chaumont, A. Chaumont, N. Kyritsakas, P. Mobian and M. Henry, Dalton Trans., 2016, 45, 21, 8760-8769; C. Chaumont, P. Mobian and M. Henry, Dalton Trans., 2014, 43, 34163419 .

${ }^{16}$ M. J. Frisch, G. W. Trucks, H. B. Schlegel, G. E. Scuseria, M. A. Robb, J. R. Cheeseman, G. Scalmani, V. Barone, B. Mennucci, G. A. Petersson, H. Nakatsuji, M. Caricato, X. Li, H. P. Hratchian, A. F. Izmaylov, J. Bloino, G. Zheng, J. L. Sonnenberg, M. Hada, M. Ehara, K. Toyota, R. Fukuda, J. Hasegawa, M. Ishida, T. Nakajima, Y. Honda, O. Kitao, H. Nakai, T. Vreven, Jr., J. A. Montgomery, J. E. Peralta, F. Ogliaro, M. Bearpark, J. J. Heyd, E. Brothers, K. N. Kudin, V. N. Staroverov, R. Kobayashi, J. Normand, K. Raghavachari, A. Rendell, J. C. Burant, S. S. Iyengar, J. Tomasi, M. Cossi, N. Rega, J. M. Millam, M. Klene, J. E. Knox, J. B. Cross, V. Bakken, C. Adamo, J. Jaramillo, R. Gomperts, R. E. Stratmann, O. Yazyev, A. J. Austin, R. Cammi, C. Pomelli, J. W. Ochterski, R. L. Martin, K. Morokuma, V. G. Zakrzewski, G. A. Voth, P. Salvador, J. J. Dannenberg, S. Dapprich, A. D. Daniels, Ö. Farkas, J. B. Foresman, J. V. Ortiz, J. Cioslowski and D. J. Fox, Gaussian 09, Revision D.01 Gaussian, Inc., Wallingford CT, 2009.

${ }^{17}$ M. Henry, ChemPhysChem, 2002, 3, 561.

${ }^{18}$ M. A. Spackman, J. Chem. Phys., 1986, 85, 6579.

${ }^{19}$ A. Pidcock, R. E. Richards and L.M. Venanzi, J. Chem. soc. A, 1966, 1707.

${ }^{20}$ M. Henry, in: Encyclopedia of Nanoscience and Nanotechnology (Ed.: H. S. Nalwa), American Scientific Publishers, 2011, 14, 1-43; M. Henry, in: Advances in Quantum 
Chemical Bonding Structures (Ed.: M. V. Putz), Transworld Research Network, Kerala, India, 2009, 153-211; C. Carpanese, S. Ferlay, N. Kyritsakas, M. Henry and M. W. Hosseini, ChemComm., 2009, 1, 6786-6788; M. Henry and M. W. Hosseini, New J. Chem., 2004, 28, 897-906; (e) M. Henry, ChemPhysChem, 2002, 3, 561-569; M. Henry, ChemPhysChem, 2002, 3, 607-616.

${ }^{21}$ A. Domínguez-Martín, M. del Pilar Brandi-Blanco, A. Matilla-Hernández, H. El Bakkali, V. M. Nurchi, J. M. González-Pérez, A. Castiñeiras and J. Niclós-Gutiérrez, Coord. Chem. Rev., 2013, 257, 2814-2838.

${ }^{22}$ N. Baradel, P. Mobian, G. Khalil and M. Henry, Dalton Trans., 2017, 46, 7594-7602.

${ }^{23}$ M. A. Czarnecki, Y. Morisawa, Y. Futomi and Y. Ozaki, Chem. Rev., 2015, 115, $9707-$ 9744.

${ }^{24}$ C. Chaumont, P. Mobian, N. Kyritsakas and M. Henry, CrystEngComm, 2013, 15, 68456862; P. Mobian, C. Huguenard and M. Henry, Chem Comm., 2011, 47, 9630-9632.

${ }^{25}$ S. Scheiner, J. Phys. Chem. B., 2005, 109, 16132-16141.

${ }^{26}$ C. Diebold, P. Mobian, C. Huguenard, L. Allouche and M. Henry, Dalton Trans., 2009, 10178-10180.

${ }^{27}$ C. Diebold, D. M. Weekes, M. T. Navarrete, P. Mobian, N. Kyritsakas and M. Henry, Eur. J. Org. Chem., 2010, 6949-6956.

${ }^{28}$ Bruker (2001). SADABS. Bruker AXS Inc., Madison, Wisconsin, USA.

${ }^{29}$ G. M. Sheldrick, Acta Crystallogr. Sect. A: Found. Crystallogr., 2008, 64, 112-122.

${ }^{30}$ G. M. Sheldrick, Acta Crystallogr. Sect. C: Struct. Chem., 2015, 71, 3-8.

${ }^{31}$ R. A. Kendall, T. H. Dunning Jr., and R. J. Harrison, J. Chem. Phys., 1992, 96, 6796-806. 